\title{
Preparation of catechin extracts and nanoemulsions from green tea leaf waste and their inhibition effect on prostate cancer cell PC-3
}

This article was published in the following Dove Press journal:

International Journal of Nanomedicine

6 May 2016

Number of times this article has been viewed

\author{
Yin-Jieh Tsai \\ Bing-Huei Chen \\ Department of Food Science, Fu Jen \\ Catholic University, New Taipei City, \\ Taiwan, Republic of China
}

\begin{abstract}
Green tea is one of the most commonly consumed natural health beverages in Taiwan's market, with the major functional component catechin being shown to possess several biological activities such as antioxidation, anticancer, and prevention of cardiovascular disease. The objectives of this study were to develop a high-performance liquid chromatography-mass spectrometry method to determine the variety and content of catechins in green tea leaf waste, a by-product obtained during processing of tea beverage. In addition, catechin nanoemulsion was prepared to study its inhibition effect on prostate cancer cell PC-3. Results showed that a total of eight catechin standards were separated within 25 minutes by using a Gemini C18 column and a gradient mobile phase of $0.1 \%$ formic acid (A) and acetonitrile (B) with flow rate at $1 \mathrm{~mL} / \mathrm{min}$, column temperature at $30^{\circ} \mathrm{C}$, and detection wavelength at $280 \mathrm{~nm}$. Among various extraction solvents, $50 \%$ ethanol generated the highest yield of total catechins from tea leaf waste, of which five catechins were identified and quantified. The catechin nanoemulsion was composed of catechin extract, lecithin, Tween 80 , and deionized water in an appropriate proportion, with the mean particle size being $11.45 \mathrm{~nm}$, encapsulation efficiency $88.1 \%$, and zeta potential $-66.3 \mathrm{mV}$. A high stability of catechin nanoemulsion was shown over a storage period of 120 days at $4^{\circ} \mathrm{C}$. Both catechin extract and nanoemulsion could inhibit growth of PC-3 tumor cells, with the half maximal inhibitory concentration being $15.4 \mu \mathrm{g} / \mathrm{mL}$ and $8.5 \mu \mathrm{g} / \mathrm{mL}$, respectively. The PC-3 cell cycle was arrested at S phase through elevation of P27 expression and decline of cyclin A, cyclin B, cyclin-dependent kinase 2, and cyclin-dependent kinase 1 expression. In addition, both catechin extract and nanoemulsion could induce apoptosis of PC-3 cells through decrease in B-cell lymphoma 2 (bcl-2) expression and increase in cytochrome c expression for activation of caspase-3, caspase-8, and caspase-9. Taken together, both caspasedependent and caspase-independent pathways may be involved in apoptosis of PC-3 cells.
\end{abstract}

Keywords: green tea leaf waste, HPLC-MS, catechin nanoemulsion, prostate cancer cell PC-3, apoptosis

\section{Introduction}

Camellia sinensis (L.) Kuntze, also known as "Tea Tree" widely grown in Asian countries such as Taiwan, the People's Republic of China, Japan, and Sri Lanka, contains two major varieties, var. sinensis and var. assamica. ${ }^{1}$ According to the degree of fermentation, tea beverage made from tea leaves can be divided into nonfermented tea, semifermented tea, and fermented tea, with green tea, Oo-long tea, and black tea being the most important commercial tea beverage products, respectively. In addition, tea beverage made from tea leaves has gained popularity since its production in 1989 in Taiwan. According to a statistical report by the Ministry of Economics in Taiwan,
Correspondence: Bing-Huei Chen Department of Food Science, Fu Jen Catholic University, 510 Chong-Cheng Road, Hsin-chuang District, New Taipei City 242, Taiwan, Republic of China

Tel +8862 29053626

$\mathrm{Fax}+88622209327 \mathrm{I}$

Email 002622@mail.fju.edu.tw
International Journal of Nanomedicine 2016:I | 1907-1926

Dovepress

http://dx.doi.org/1 0.2147/IJN.SI 03759 (c) (i) (c) 2016 Isai and Chen. This work is published and licensed by Dove Medical Press Limited. The full terms of this license are available at https://www.dovepress.com/terms.php cc) ${ }_{\mathrm{BY}} \mathrm{NC}$ and incorporate the Creative Commons Attribution - Non Commercial (unported, v3.0) License (http://creativecommons.org/licenses/by-nc/3.0/). By accessing the work you hereby accept the Terms. Non-commercial uses of the work are permitted without any further permission from Dove Medical Press Limited, provided the work is properly attributed. For permission for commercial use of this work, please see paragraphs 4.2 and 5 of our Terms (https://www.dovepress.com/terms.php). 
tea beverage production has increased steadily every year and the total market value has reached $\sim 24$ billion New Taiwan dollars in 2014. ${ }^{2}$ However, a large amount of tea leaf waste can be produced during tea beverage processing, which can pose a major problem to environmental protection.

Of the various tea beverage products, green tea has received considerable attention in the past decades as numerous studies have demonstrated that the consumption of green tea can be protective against chronic diseases such as liver damage, ${ }^{3}$ inflammation, ${ }^{4}$ renal carcinoma, ${ }^{5}$ and cardiovascular disease, ${ }^{6}$ all of which can be associated with presence of the major functional components - catechins. Catechins, a class of flavanols, can be divided into epistructured catechin and nonepistructured catechin, with the former including epicatechin (EC), epicatechin gallate (ECG), epigallocatechin (EGC), and epigallocatechin gallate (EGCG) and the latter including catechin $(\mathrm{C})$, catechin gallate (CG), gallocatechin (GC), and gallocatechin gallate (GCG). ${ }^{7}$ Among them, EGCG is the most abundant one as it constitutes $\sim 50 \%$ of total catechins in dried green tea leaves. ${ }^{8}$ As tea leaf waste is also a rich source of catechins, ${ }^{9}$ it would be a great advantage to the tea beverage industry to isolate catechins from tea leaf waste for further commercial production and utilization as a nutritional supplement or as an anticancer agent.

Due to high-polarity nature of catechins, catechins in tea leaves are often extracted with polar solvents such as methanol, ethanol, acetonitrile, and acetone alone or in combination. ${ }^{10}$ However, it has been reported that the extraction efficiency of catechins can be greatly enhanced by using a combination of solvents instead of a single solvent. ${ }^{11}$ For instance, Liang et $\mathrm{al}^{11}$ compared the effect of various proportions of ethanol in water $(10 \%, 20 \%, 50 \%, 70 \%$, and $90 \%$ ) on the extraction yield of catechins in Long-Jin tea leaves and found that a high yield was attained by $30 \%-70 \%$ ethanol, while a low yield was obtained by $90 \%$ ethanol. Following extraction, catechins are often subjected to highperformance liquid chromatography-mass spectrometry (HPLC-MS) for separation, identification, and quantitation. For HPLC separation, the acidic modifiers such as formic acid, phosphoric acid, and acetic acid are often incorporated into polar mobile phases composed of water-acetonitrile or water-methanol to prevent peak tailing or broadening by using a C18 reversed-phase column. ${ }^{12,13}$ However, the composition of catechins in green tea leaf waste remains uncertain. Thus, it is a necessity to develop an HPLC-MS method for determination of various catechins in green tea leaf waste.
Over the past 32 years, malignant tumors have been the leading cause of death in Taiwan, in which prostate cancer ranks sixth and accounts for $10.3 \%$ of the ten most prevalent cancers, according to a statistical report issued by the Ministry of Health. ${ }^{14}$ As mentioned previously, catechins have been reported to possess vital biological activities. However, because of instability, the bioavailability of catechins in vivo remained low. ${ }^{15-17}$ Thus, through preparation of microemulsion or nanoemulsion for encapsulation of bioactive compounds such as catechin, it is possible to enhance stability so that both bioavailability and biological activity of catechins can be greatly enhanced. More importantly, the efficiency dose of catechins can be reduced substantially to minimize side effects. Numerous studies have been carried out regarding the biological activities of catechins. Among the various catechins, EGCG was investigated most often due to its high biological activity and presence of an abundant amount of green tea leaves. For instance, Cavet et $\mathrm{al}^{4}$ studied the effect of EGCG $(3-30 \mu \mathrm{M})$ on IL-1 $\beta$-induced inflammation of human corneal epithelial cells and reported that the various cytokines such as IL-8 and IL-6, as well as chemokines such as monocyte chemoattractant protein-1, were inhibited. Similarly, EGCG $(50 \mu \mathrm{M})$ was reported to inhibit IL-1 $\beta$-induced inflammation of human synovial fibroblast cells through decrease in the expressions of COX-2, PEG2, and IL-8. In addition to EGCG, green tea extract (31.3-500 $\mu \mathrm{g} / \mathrm{mL})$ was shown to inhibit growth of kidney cancer cells A-497 and 769-P, with the half maximal inhibitory concentration $\left(\mathrm{IC}_{50}\right.$ ) being $54 \mu \mathrm{g} / \mathrm{mL}$ and $129 \mu \mathrm{g} / \mathrm{mL}$, respectively. ${ }^{5}$ Similarly, after treatment of prostate cancer cell PC-3 with black tea extract ( $40-80 \mu \mathrm{g} / \mathrm{mL})$, a dose-dependent inhibition was observed with the $\mathrm{IC}_{50}$ being $60 \mu \mathrm{g} / \mathrm{mL}{ }^{18}$ In addition, the expressions of $\mathrm{P} 21$, caspase- 9 , and caspase- 3 were elevated, while the expressions of B-cell lymphoma 2 (bcl-2) and cyclin B declined, leading to cell cycle arrest at G2/M phase for subsequent apoptosis. ${ }^{18}$ Thus, the objectives of our study were to develop a better HPLC-MS method for separation of eight catechin standards and quantitation of catechins in green tea leaf waste. Meanwhile, catechin nanoemulsion was prepared to study its inhibition effect on prostate cancer cell PC-3.

\section{Materials and methods Materials}

Approximately $1 \mathrm{~kg}$ of tea leaf waste from $C$. sinensis (L.) Kuntze was provided by a tea beverage processing plant located in Tainan, Taiwan. Then, the tea leaf waste samples were transported to our laboratory, freeze-dried, ground into 
powder, placed into separate bags, sealed under vacuum, and stored at $-30^{\circ} \mathrm{C}$ until use. Catechin standards including catechin, EC, GC, EGC, GCG, and EGCG, as well as internal standard L-tryptophan, were procured from Sigma-Aldrich Co. (St Louis, MO, USA). HPLC-grade solvents including ethanol, methanol, and acetonitrile were obtained from Merck Millipore (Darmstadt, Germany). Formic acid was also from Sigma-Aldrich Co. Deionized water was made by a Milli-Q water purification system from Merck Millipore. Three HPLC columns, including Gemini C18 110A (column length $[\mathrm{CL}]=250 \mathrm{~mm}$, internal diameter $[\mathrm{ID}]=4.6 \mathrm{~mm}$, particle size $[\mathrm{PS}]=5 \mu \mathrm{m})$, Vydac 201TP54 C18 $(\mathrm{CL}=250 \mathrm{~mm}$, $\mathrm{ID}=4.6 \mathrm{~mm}, \mathrm{PS}=5 \mu \mathrm{m})$, and TSK gel ODS-80Tm $\mathrm{C} 18$ ( $\mathrm{CL}=250 \mathrm{~mm}, \mathrm{ID}=4.6 \mathrm{~mm}, \mathrm{PS}=5 \mu \mathrm{m})$, were purchased from Phenomenex Co. (Torrance, CA, USA), Vydac Co. (Hesperia, CA, USA), and Tosoh Co. (Tokyo, Japan), respectively.

\section{Instrumentation}

The HPLC instrument is composed of two Jasco PU980 and PU1980 pumps, a Rheodyne 7161 injector, a Jasco MD915 photodiode array detector, a Borwin software system (Jasco Co., Tokyo, Japan), and an Agilent 6130 single quadrupole mass spectrometer with multimode ion source (electrospray ionization and atmospheric pressure chemical ionization; Agilent Technologies, Santa Clara, CA, USA). A FD24 freeze dryer was from Chin-Ming Co. (Taipei, Taiwan). The Eyela N-1 rotary evaporator with an A3-S vacuum pump was from Eyela (Tokyo, Japan). The ultrasonicator (DC 400H) was from Chuan-Hua Co. (Taipei, Taiwan). The Sorvall RC5C high-speed centrifuge was from Du Pont Co. (Wilmington, DL, USA).

\section{Evaluation of extraction efficiency}

A method based on Lin et al, ${ }^{19}$ Vuong et al, ${ }^{20}$ and Lin et $\mathrm{al}^{21}$ was modified. A $0.2 \mathrm{~g}$ tea leaf waste powder sample was mixed with $4 \mathrm{~mL}$ of $30 \%, 50 \%$, or $70 \%$ ethanol solution, after which each mixture was sonicated at room temperature for 1 hour. Then, the solution was centrifuged for 30 minutes $\left(4,000 \mathrm{rpm}, 25^{\circ} \mathrm{C}\right)$. The supernatant was collected, evaporated to dryness under vacuum, dissolved in $50 \%$ ethanol, diluted to $5 \mathrm{~mL}$, filtered through a $0.22-\mu \mathrm{m}$ membrane filter, and stored at $-20^{\circ} \mathrm{C}$ for use.

\section{Evaluation of column efficiency}

Three columns described above were used for evaluation of separation efficiency. In the beginning, a mobile phase of $0.1 \%$ formic acid solution (A) and acetonitrile (B) with the following gradient elution based on a study by $\mathrm{Wu}$ et $\mathrm{al}^{22}$ was used: $95 \% \mathrm{~A}$ and $5 \% \mathrm{~B}$ in the beginning, changed to $15 \% \mathrm{~B}$ at 14 minutes, maintained for 11 minutes, changed to $35 \%$ at 53 minutes, and returned to original ratio at 55 minutes. The column temperature was $30^{\circ} \mathrm{C}$, with flow rate at $1 \mathrm{~mL} / \mathrm{min}$ and detection wavelength at $280 \mathrm{~nm}$. However, by using this method, the resolution of eight catechin standards remained inadequate for all the three columns. Thus, a modification is necessary. After many trials, a Gemini C18 column with a gradient mobile phase of $0.1 \%$ formic acid solution (A) and acetonitrile (B) was developed: $88 \% \mathrm{~A}$ and $12 \% \mathrm{~B}$ initially, changed to $85 \% \mathrm{~A}$ at 3 minutes, maintained for 3 minutes, changed to $80 \% \mathrm{~A}$ at 18 minutes, $68 \% \mathrm{~A}$ at 28 minutes, and maintained for 2 minutes. A total of eight catechin standards were separated within 25 minutes with flow rate of $1 \mathrm{~mL} /$ min, column temperature at $30^{\circ} \mathrm{C}$, and detection wavelength of $280 \mathrm{~nm}$.

\section{Identification and quantitation of catechins}

The various catechins in green tea leaf waste were identified by comparing retention time, absorption spectra, and mass spectra of unknown peaks with reference standards. A negative mode (electrospray ionization) with scanning was used for detection: the scanning molecular weight range $100-1,000 \mathrm{~m} / \mathrm{z}$, drying gas flow $13 \mathrm{~mL} / \mathrm{min}$, nebulizer pressure $60 \mathrm{psi}$, dry gas temperature $350^{\circ} \mathrm{C}$, vaporizer temperature $250^{\circ} \mathrm{C}$, capillary voltage $3,500 \mathrm{~V}$, charging voltage $2,000 \mathrm{~V}$, and fragmentor voltage $80 \mathrm{~V}$ and $200 \mathrm{~V}$. For quantitation, an internal standard L-tryptophan was used and dissolved in 50\% ethanol solution for a concentration of $1,000 \mu \mathrm{g} / \mathrm{mL}$. Then, six concentrations of various catechin standards dissolved in $50 \%$ ethanol were prepared: $1.5 \mu \mathrm{g} / \mathrm{mL}, 3 \mu \mathrm{g} / \mathrm{mL}, 5 \mu \mathrm{g} / \mathrm{mL}$, $8 \mu \mathrm{g} / \mathrm{mL}, 10 \mu \mathrm{g} / \mathrm{mL}$, and $12 \mu \mathrm{g} / \mathrm{mL}$ for $\mathrm{GC} ; 5 \mu \mathrm{g} / \mathrm{mL}$, $10 \mu \mathrm{g} / \mathrm{mL}, 15 \mu \mathrm{g} / \mathrm{mL}, 20 \mu \mathrm{g} / \mathrm{mL}, 25 \mu \mathrm{g} / \mathrm{mL}$, and $30 \mu \mathrm{g} / \mathrm{mL}$ for EGC; $30 \mu \mathrm{g} / \mathrm{mL}, 50 \mu \mathrm{g} / \mathrm{mL}, 100 \mu \mathrm{g} / \mathrm{mL}, 150 \mu \mathrm{g} / \mathrm{mL}$, $200 \mu \mathrm{g} / \mathrm{mL}$, and $300 \mu \mathrm{g} / \mathrm{mL}$ for EGCG; $1.0 \mu \mathrm{g} / \mathrm{mL}, 2 \mu \mathrm{g} / \mathrm{mL}$, $5 \mu \mathrm{g} / \mathrm{mL}, 10 \mu \mathrm{g} / \mathrm{mL}, 20 \mu \mathrm{g} / \mathrm{mL}$, and $30 \mu \mathrm{g} / \mathrm{mL}$ for GCG; $10 \mu \mathrm{g} / \mathrm{mL}, 20 \mu \mathrm{g} / \mathrm{mL}, 40 \mu \mathrm{g} / \mathrm{mL}, 60 \mu \mathrm{g} / \mathrm{mL}, 80 \mu \mathrm{g} / \mathrm{mL}$, and $100 \mu \mathrm{g} / \mathrm{mL}$ for ECG. Each catechin standard solution was then mixed with the internal standard solution whose final concentration was fixed at $10 \mu \mathrm{g} / \mathrm{mL}$. Next, $20 \mu \mathrm{L}$ of each concentration of the standard solution was injected into HPLC twice, and the various standards' curves were obtained by plotting concentration ratio (standard vs internal standard) against area ratio (standard vs internal standard), with the linear regression equations and correlation coefficient $(R)$ being obtained automatically with a Microsoft Excel software system. 


\section{Method validation}

The intraday variability and interday variability were determined based on a method described by the International Conference on Harmonization..$^{23}$ The former was carried out by analyzing sample solutions containing internal standard $(10 \mu \mathrm{g} / \mathrm{mL})$ in the morning, afternoon, and evening of the same day and injecting three times each for a total of nine injections. Similarly, the latter was performed by analyzing sample solutions containing internal standard $(10 \mu \mathrm{g} / \mathrm{mL})$ in the morning, afternoon, and evening of the first, second, and third days and injecting once for a total of nine injections. For determination of limit of detection (LOD) and limit of quantitation (LOQ), three concentrations of catechin standards were prepared: $0.2 \mu \mathrm{g} / \mathrm{mL}, 0.35 \mu \mathrm{g} / \mathrm{mL}$, and $0.4 \mu \mathrm{g} / \mathrm{mL}$ for $\mathrm{GC} ; 0.2 \mu \mathrm{g} / \mathrm{mL}, 0.4 \mu \mathrm{g} / \mathrm{mL}$, and $0.6 \mu \mathrm{g} / \mathrm{mL}$ for EGC; $0.2 \mu \mathrm{g} / \mathrm{mL}, 0.4 \mu \mathrm{g} / \mathrm{mL}$, and $0.6 \mu \mathrm{g} / \mathrm{mL}$ for both EGCG and GCG; and $0.2 \mu \mathrm{g} / \mathrm{mL}, 0.25 \mu \mathrm{g} / \mathrm{mL}$, and $0.3 \mu \mathrm{g} / \mathrm{mL}$ for ECG. Each concentration was injected into HPLC three times, and the standard curves were obtained by plotting concentration against height, with the linear regression equations, slope $(s)$, and maximum noise height (Np-p) being obtained, and both LOD and LOQ were calculated. ${ }^{23}$

For recovery determination, two levels of catechin standards were added to samples $(0.2 \mathrm{~g})$ for extraction and HPLC analysis: GC (14 $\mu \mathrm{g}$ and $21 \mu \mathrm{g})$, EGC (100 $\mu \mathrm{g}$ and $150 \mu \mathrm{g})$, EGCG $(500 \mu \mathrm{g}$ and $1,000 \mu \mathrm{g})$, GCG $(160 \mu \mathrm{g}$ and $240 \mu \mathrm{g})$, and ECG (170 $\mu \mathrm{g}$ and $350 \mu \mathrm{g})$. The recovery of each catechin standard was calculated based on the ratio of the amount of catechin standard after HPLC relative to that before HPLC. Then, the various catechins in green tea leaf waste samples were calculated using a method described by Chang and Chen. ${ }^{24}$

\section{Preparation of catechin nanoemulsion}

Initially, a portion of catechin extract was collected and poured into a tube. After evaporation to dryness under nitrogen, $0.05 \mathrm{~g}$ of lecithin $(0.5 \%)$ was added and stirred. Then, $0.5 \mathrm{~g}$ of Tween 80 (5\%) was added and stirred again, followed by adding $9.45 \mathrm{~g}$ of deionized water (94.5\%). After mixing homogeneously, this mixture was shaken in a sonicator for 1.5 hours to obtain a transparent catechin nanoemulsion with yellow appearance.

\section{Determination of nanoemulsion characteristics}

A portion of catechin nanoemulsion $(500 \mu \mathrm{L})$ was collected and diluted to $5 \mathrm{~mL}$ in a tube with phosphoric acid dihydrogen potassium buffer solution ( $\mathrm{pH}$ 5.3-5.5). After filtration through a $0.22 \mu \mathrm{m}$ membrane filter, the nanoemulsion size was determined by a dynamic light scattering (DLS) analyzer. For transmission electron microscope (TEM) analysis, a portion of catechin nanoemulsion was diluted 100 times with deionized water. Then, a $20 \mu \mathrm{L}$ sample was collected and dropped onto a copper grid for 40 seconds. After removal of excessive sample with a glass filter paper, $2 \%$ phosphotungstic acid $(20 \mu \mathrm{L})$ was added for negative staining for 30 seconds, followed by removing the excessive staining agent with a glass filter paper and placing into an incubator for complete dryness. Then, the sample was enlarged $3 \times 10^{5}$ times with $120 \mathrm{kV}$ for observation of size and shape.

\section{Determination of zeta potential}

One milliliter of catechin nanoemulsion was diluted with deionized water and then placed into a zeta potential analyzer for zeta potential determination with temperature at $25^{\circ} \mathrm{C}$ and zeta potential range from $-200 \mathrm{mV}$ to $+200 \mathrm{mV}$.

\section{Determination of encapsulation efficiency}

A portion of catechin nanoemulsion $(100 \mu \mathrm{L})$ was diluted ten times with $25 \mathrm{mM}$ of phosphoric acid dihydrogen potassium buffer solution ( $\mathrm{pH}$ 5.5). Then, the solution was poured into a centrifuge tube containing a membrane with the molecular weight cutoff $3 \mathrm{kDa}$. After centrifuging at $12,000 \mathrm{rpm}$ for 20 minutes, a portion of the lower layer solution $(200 \mu \mathrm{L})$ was collected and evaporated to dryness, followed by dissolving in $50 \%$ ethanol solution containing $10 \mathrm{ppm}$ internal standard L-tryptophan for HPLC analysis of free catechin. Then, the encapsulation efficiency was calculated using a formula described by Chang and Chen. ${ }^{24}$

\section{Stability of catechin nanoemulsion}

Catechin nanoemulsion was stored at $4{ }^{\circ} \mathrm{C}$ for 120 days, during which the particle size and distribution were determined by DLS on days $0,7,60$, and 120 . In addition, the encapsulation efficiency was determined on days 0 and 120 .

\section{Cell culture}

Human prostate cancer cell PC-3 was cultured in F-12K medium containing $7 \%$ fetal bovine serum and $100 \mathrm{U} / \mathrm{mL}$ of penicillin-streptomycin, while human fibroblast cell CCD-986SK was cultured in Dulbecco's Modified Eagle's Medium (DMEM) containing 10\% fetal bovine serum and $100 \mathrm{U} / \mathrm{mL}$ of penicillin-streptomycin. After collection and thawing in $37^{\circ} \mathrm{C}$ water bath, cells containing $10 \%$ dimethyl sulfoxide were placed into a $10 \mathrm{~cm}$ plate, followed by addition of $7 \mathrm{~mL}$ of F-12K or DMEM and incubation in an 
incubator containing $5 \% \mathrm{CO}_{2}$ with temperature at $37^{\circ} \mathrm{C}$ and relative humidity at $100 \%$. For subculture of PC-3 or CCD986SK cells, the medium was removed and washed with $9 \mathrm{~mL}$ of phosphate-buffered saline (PBS) twice, followed by addition of $0.25 \%$ of $1 \mathrm{~mL}$ of trypsin-EDTA and reaction for 3-5 minutes until cells suspended. Then, $1 \mathrm{~mL}$ of F-12K or DMEM was added to terminate trypsin-EDTA reaction and the solution transferred to a $15 \mathrm{~mL}$ centrifuge tube for centrifugation at $1,000 \mathrm{rpm}$ for 5 minutes at $25^{\circ} \mathrm{C}$. The supernatant was aspirated, and then $1 \mathrm{~mL}$ of F-12K or DMEM was added. Next, a suitable amount of cells were collected and seeded onto a $10 \mathrm{~cm}$ plate, followed by addition of $10 \mathrm{~mL}$ of F-12K or DMEM, and incubation in an incubator containing $5 \% \mathrm{CO}_{2}$ with temperature at $37^{\circ} \mathrm{C}$ and relative humidity at $100 \%$. The approval for carrying out the entire experiment was approved by the institutional ethics committee of Fu Jen Catholic University, New Taipei City, Taiwan.

\section{MTT assay}

Initially, $50 \mathrm{mg}$ of MTT powder was dissolved in $10 \mathrm{~mL}$ sterilized PBS and filtered through a $0.22 \mu \mathrm{m}$ membrane filter to obtain a $5 \mathrm{mg} / \mathrm{mL}$ MTT solution. Prior to experiment, the MTT solution was diluted with Hanks' balanced salt solution at a ratio of 1:9 (v:v). Then, the cell suspension of PC-3 or CCD-986SK was seeded in a 96-well plate with each well containing $5 \times 10^{3}$ cells, and cultured for 24 hours for cell adhesion. After removal of culture medium, seven concentrations $(1.25 \mu \mathrm{g} / \mathrm{mL}, 2.5 \mu \mathrm{g} / \mathrm{mL}, 5 \mu \mathrm{g} / \mathrm{mL}, 7.5 \mu \mathrm{g} / \mathrm{mL}$, $10 \mu \mathrm{g} / \mathrm{mL}, 20 \mu \mathrm{g} / \mathrm{mL}$, and $30 \mu \mathrm{g} / \mathrm{mL}$ ) of catechin extracts or five concentrations $(1.25 \mu \mathrm{g} / \mathrm{mL}, 2.5 \mu \mathrm{g} / \mathrm{mL}, 5 \mu \mathrm{g} / \mathrm{mL}$, $7.5 \mu \mathrm{g} / \mathrm{mL}$, and $10 \mu \mathrm{g} / \mathrm{mL}$ ) of catechin nanoemulsions were added. Triplicate experiments were performed for each concentration. After incubation for 72 hours, the medium was removed, and $200 \mu \mathrm{L}$ of MTT solution $(0.5 \mathrm{mg} / \mathrm{mL})$ was added to each well and reacted in the dark for 2 hours. Then, the MTT solution was removed, followed by addition of $200 \mu \mathrm{L}$ of dimethyl sulfoxide to dissolve purple crystals and measurement of absorbance at $570 \mathrm{~nm}$ with an ELISA reader. The cell viability was calculated using a method described by Chang and Chen. ${ }^{24}$

\section{Cell cycle analysis}

PC-3 cells $\left(5 \times 10^{4}\right)$ were seeded in a six-well plate and incubated for 24 hours for cell adhesion. After removal of F-12K medium, three concentrations $(7.5 \mu \mathrm{g} / \mathrm{mL}, 10 \mu \mathrm{g} / \mathrm{mL}$, and $20 \mu \mathrm{g} / \mathrm{mL})$ of catechin extract or catechin nanoemulsion $(5 \mu \mathrm{g} / \mathrm{mL}, 7.5 \mu \mathrm{g} / \mathrm{mL}$, and $10 \mu \mathrm{g} / \mathrm{mL})$ were added and incubated for 72 hours. Then, the medium was removed, and cells were washed with PBS, followed by adding $1 \mathrm{~mL}$ of trypsin-EDTA and collecting cells in a centrifuge tube for centrifugation at $1,200 \mathrm{rpm}$ for 5 minutes $\left(4^{\circ} \mathrm{C}\right)$. Next, the supernatant was removed, and cells were washed with PBS twice, followed by adding $1 \mathrm{~mL}$ of PBS containing $70 \%$ ethanol for cell fixation at $4{ }^{\circ} \mathrm{C}$. Then, the cells were centrifuged at 2,000 rpm for 5 minutes and washed with PBS twice, after which $0.8 \mathrm{~mL}$ of PBS, $0.1 \mathrm{~mL}$ of RNase $(1 \mathrm{mg} / \mathrm{mL})$, and $0.1 \mathrm{~mL}$ propidium iodine $(0.1 \mathrm{mg} / \mathrm{mL})$ were added for reaction at $37^{\circ} \mathrm{C}$ for 30 minutes in the dark. Then, the stained cells were analyzed by a flow cytometer for cell cycle distribution, including sub-G1, G0/G1, S, and $\mathrm{G} 2 / \mathrm{M}$ phases.

\section{Annexin $\mathrm{V} /$ propidium iodide staining assay}

PC-3 cells $\left(5 \times 10^{4}\right)$ were seeded in a six-well plate and cultured for 24 hours for cell adhesion, after which the F-12K medium was removed and three concentrations of catechin extract $(7.5 \mu \mathrm{g} / \mathrm{mL}, 10 \mu \mathrm{g} / \mathrm{mL}$, and $20 \mu \mathrm{g} / \mathrm{mL})$ or catechin nanoemulsion $(5 \mu \mathrm{g} / \mathrm{mL}, 7.5 \mu \mathrm{g} / \mathrm{mL}$, and $10 \mu \mathrm{g} / \mathrm{mL})$ were added. Triplicate experiments were carried out for each concentration. After incubation for 72 hours, the cells were washed with PBS, and $1 \mathrm{~mL}$ of trypsin-EDTA was added to detach the cells. Then, the cells were collected and centrifuged at 1,200 rpm for 5 minutes $\left(4^{\circ} \mathrm{C}\right)$, followed by removing supernatant, washing with PBS, suspending cells with $0.1 \mathrm{~mL}$ of binding buffer $(1 \times)$, adding $5 \mu \mathrm{L}$ of FITC-Annexin $\mathrm{V}$, and $10 \mu \mathrm{L}$ of propidium iodide (PI; staining agent) in the dark. After reaction at room temperature for 15 minutes, $0.4 \mathrm{~mL}$ of binding buffer $(1 \times)$ was added to analyze apoptotic and necrotic cell populations by a flow cytometer.

\section{Western blotting}

PC-3 cells $\left(3.5 \times 10^{4}\right)$ were seeded in a ten-well plate and cultured for 24 hours for cell adhesion, after which the medium was removed, and three concentrations of catechin extract (7.5 $\mu \mathrm{g} / \mathrm{mL}, 10 \mu \mathrm{g} / \mathrm{mL}$, and $20 \mu \mathrm{g} / \mathrm{mL})$ or catechin nanoemulsion $(5 \mu \mathrm{g} / \mathrm{mL}, 7.5 \mu \mathrm{g} / \mathrm{mL}$, and $10 \mu \mathrm{g} / \mathrm{mL})$ were added. Triplicate experiments were conducted for each concentration. After incubation for 72 hours, the cells were washed with PBS, and $1 \mathrm{~mL}$ of trypsin-EDTA was added for cell collection and subsequent centrifugation at 1,200 rpm for 5 minutes $\left(4^{\circ} \mathrm{C}\right)$. Then, the supernatant was removed, cells were washed with PBS, and $0.1 \mathrm{~mL}$ of lysis buffer $(1 \times)$ was added to disperse cells by sonication. After storage at $-20^{\circ} \mathrm{C}$ overnight, cells were centrifuged at $12,000 \mathrm{rpm}$ for 30 minutes, and the supernatant containing cell protein was collected for protein quantitation. The protein standard curve of bovine serum 
albumin was prepared by plotting various concentrations of bovine serum albumin against absorbance at $595 \mathrm{~nm}$. Then, $2 \mathrm{~mL}$ of cell protein sample and $1 \mathrm{~mL}$ of Bradford staining agent $(1 \times)$ were mixed in the dark, after which $0.2 \mathrm{~mL}$ of sample was transferred to a 96-well plate for absorbance measurement at $595 \mathrm{~nm}$. The protein concentration in each sample was quantified based on the standard curve. Next, a $40 \mu \mathrm{g}$ cell protein sample was mixed with sample buffer for reaction in a $95^{\circ} \mathrm{C}$ water bath for 5 minutes for protein denaturation and then cooled on ice. Protein samples were then added to a tank for protein separation on $12 \%$ sodium dodecyl sulfate-polyacrylamide gel at $70 \mathrm{~V}$ for 30 minutes, followed by separation at $110 \mathrm{~V}$ for 1.5 hours to allow migration of sample buffer solution to the gel bottom.

For Western blotting, the separated proteins were transferred onto a polyvinylidene difluoride membrane, which was preactivated in methanol for 1 minute and then soaked in transfer buffer for 1 minute. After incubation at $4^{\circ} \mathrm{C}$ and $100 \mathrm{~V}$ for 1.5 hours, the polyvinylidene difluoride membrane was collected and soaked in buffer solution containing 5\% skim milk, for shaking for 2 hours. Then, the Tris-buffered saline with Tween 20 (TBST) buffer solution was added for washing, three times for 10 minutes each, to remove unattached protein. Finally, the primary antibody diluted with TBST in an appropriate ratio was added: P27 (1:500), cyclin A (1:750), cyclin-dependent kinase 2 (CDK2; 1:2,000), bcl-2 (1:2,000), cyclin B (1:750), cytochrome C (1:500), cyclindependent kinase 1 (CDK1; 1:2,000), and glyceraldehyde 3-phosphate dehydrogenase (GAPDH; 1:1,000). After overnight reaction at $4^{\circ} \mathrm{C}$, the TBST buffer solution was added for washing, three times for 10 minutes each. Then, the secondary antibody (antirabbit or antimouse) diluted with TBST buffer solution 5,000 times was added for reaction for 1 hour, followed by washing with TBST, three times for 10 minutes each; the enhanced chemiluminescence (ECL) reagent was added to enhance chemiluminescence for detection by a BioSpectrum 500 image analysis system.

\section{Expression of caspase- $3,-8$, and -9}

The PC-3 cells $\left(1 \times 10^{5}\right)$ were seeded in a six-well plate and cultured for 24 hours for cell adhesion. Then, the F-12K medium was removed, and three concentrations of catechin extract $(7.5 \mu \mathrm{g} / \mathrm{mL}, 10 \mu \mathrm{g} / \mathrm{mL}$, and $20 \mu \mathrm{g} / \mathrm{mL})$ or catechin nanoemulsion $(5 \mu \mathrm{g} / \mathrm{mL}, 7.5 \mu \mathrm{g} / \mathrm{mL}$, and $10 \mu \mathrm{g} / \mathrm{mL})$ were added. Triplicate experiments were carried out for each concentration. After incubation for 72 hours, PBS was added for washing, and $100 \mu \mathrm{L}$ of lysis buffer was added to each well for scratching cells. Then, the cells were transferred to a centrifuge tube and reacted on ice for 30 minutes. For caspase-3,
$25 \mu \mathrm{L}$ of the cell medium was added to a 96-well plate, and $100 \mu \mathrm{L}$ of 4-(2-hydroxyethyl)-1-piperazineethanesulfonic acid (HEPES) buffer containing $2.5 \mu \mathrm{L}$ of $N$-acetyl-aspartylglutamyl-valyl-aspartyl-7-amino-4-methylcoumarin (ACDEVD-AMC) was added for reaction at $37^{\circ} \mathrm{C}$ for 1 hour in the dark. Then, the absorbance was measured by a fluorometer with excitation wavelength at $380 \mathrm{~nm}$ and emission wavelength at $460 \mathrm{~nm}$. As for caspase- 8 and $-9,50 \mu \mathrm{L}$ of the cell medium was added to a 96 -well plate, and $50 \mu \mathrm{L}$ of the reaction buffer $(2 \times)$ containing $0.5 \mu \mathrm{L}$ of $1.0 \mathrm{M}$ dithiothreitol and $5 \mu \mathrm{L}$ of $1 \mathrm{mM}$ leucyl-glutamyl-histidyl-aspartyl-7-amino-4-trifluoromethylcoumarin (LEHD-AFC) was added for reaction at $37^{\circ} \mathrm{C}$ for 1 hour in the dark. Then, the absorbance was measured by a fluorometer with excitation wavelength at $400 \mathrm{~nm}$ and emission wavelength at $505 \mathrm{~nm}$.

\section{Statistical analysis}

All the analyses were carried out at least in triplicate, and the data were subjected to analysis of variance and Duncan's multiple range test for significance $(P<0.05)$ in mean comparison by using the Statistical Analysis System. ${ }^{25}$

\section{Results and discussion Comparison of extraction efficiency}

Figure 1 shows the effect of different ethanol proportions on extraction efficiency of catechins in green tea leaf waste. After HPLC analysis, a high yield of EGCG and ECG was obtained with $70 \%$ ethanol or $50 \%$ ethanol, which amounted to $7,062.05 \mu \mathrm{g} / \mathrm{g}$ and $1,754.51 \mu \mathrm{g} / \mathrm{g}$, respectively,

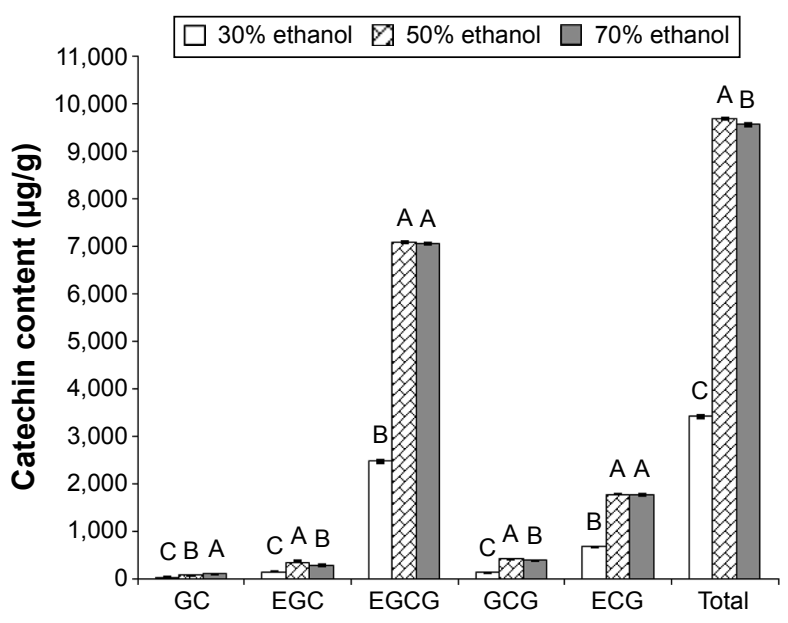

Figure I Effect of different ethanol proportions on the catechin contents in green tea leaf waste extracts.

Notes: Results are presented as mean \pm standard deviation of triplicate determinations. Data with different capital letters $(A-C)$ on each bar represent the content of each catechin or total catechin extracted using different solvents are significantly different at $P<0.05$.

Abbreviations: GC, gallocatechin; EGC, epigallocatechin; EGCG, epigallocatechin gallate; GCG, gallocatechin gallate; ECG, epicatechin gallate. 
for the former, as well as $7,086.69 \mu \mathrm{g} / \mathrm{g}$ and $1,771.83 \mu \mathrm{g} / \mathrm{g}$, respectively, for the latter. However, there was no significant difference $(P>0.05)$ in extraction yield of EGCG or ECG between $70 \%$ and $50 \%$ ethanol. For the extraction yield of EGC and GCG, a high content of $349.28 \mu \mathrm{g} / \mathrm{g}$ and $411.65 \mu \mathrm{g} / \mathrm{g}$ was obtained for $50 \%$ ethanol, respectively. But for the extraction yield of GC, a high level $(97.56 \mu \mathrm{g} / \mathrm{g})$ was obtained for $70 \%$ ethanol. Taken together, the highest yield of total catechins could be achieved by $50 \%$ ethanol, followed by $70 \%$ ethanol and $30 \%$ ethanol. It has been well established that with ultrasonic extraction, cell wall in leaves can be destroyed through cavity action, resulting in an increase in extraction yield and a reduction in extraction solvents. ${ }^{17,26}$ In addition, the ultrasonic extraction was carried out at room temperature $\left(25^{\circ} \mathrm{C}\right)$, which can prevent catechin degradation at elevated temperature. Vuong et $\mathrm{a}^{20}$ reported that catechins could undergo degradation and conversion from the epistructure type to nonepistructure type when extracted at $80^{\circ} \mathrm{C}-90^{\circ} \mathrm{C}$. In several similar studies, Lin et $\mathrm{al}^{19}$ and Choung et $\mathrm{al}^{8}$ also demonstrated that with $50 \%$ ethanol as the extraction solvent, a high yield of catechins in $\gamma$-aminobutyric acid-enriched Gabaron tea leaves was attained.

\section{Evaluation of column separation efficiency}

Three $\mathrm{C} 18$ columns as described above were compared with respect to separation efficiency of eight catechin standards and five catechins in green tea leaf waste. Though the three columns possess the same column length, ID, particle size, and stationary phase (C18), some other characteristics such as end-capping, carbon load, porosity, polymerization, and theoretical plate can still be varied. Using an HPLC gradient mobile phase developed by $\mathrm{Wu}$ et al, ${ }^{22}$ a Gemini C18 column showed a better resolution of eight catechin standards and catechins in tea leaf waste than the other two columns. Nevertheless, the separation time is lengthy (42 minutes) and needs to be further shortened. By following a gradient mobile phase of $0.1 \%$ formic acid solution (A) and acetonitrile (B) described in the "Materials and methods" section, all the eight catechin standards including GC, EGC, catechin, EC, EGCG, GCG, ECG, and CG were adequately resolved within 25 minutes (Figure 2 and Table 1). All the data indicated that an optimal mobile phase strength and a proper selectivity of mobile phase to sample components were attained. In several previous studies, Vuong et $\mathrm{al}^{20}$ used a $\mathrm{C} 18$ column ( $250 \times 4.6 \mathrm{~mm}$ ID, $5 \mu \mathrm{m}$ particle size) and a mobile phase of

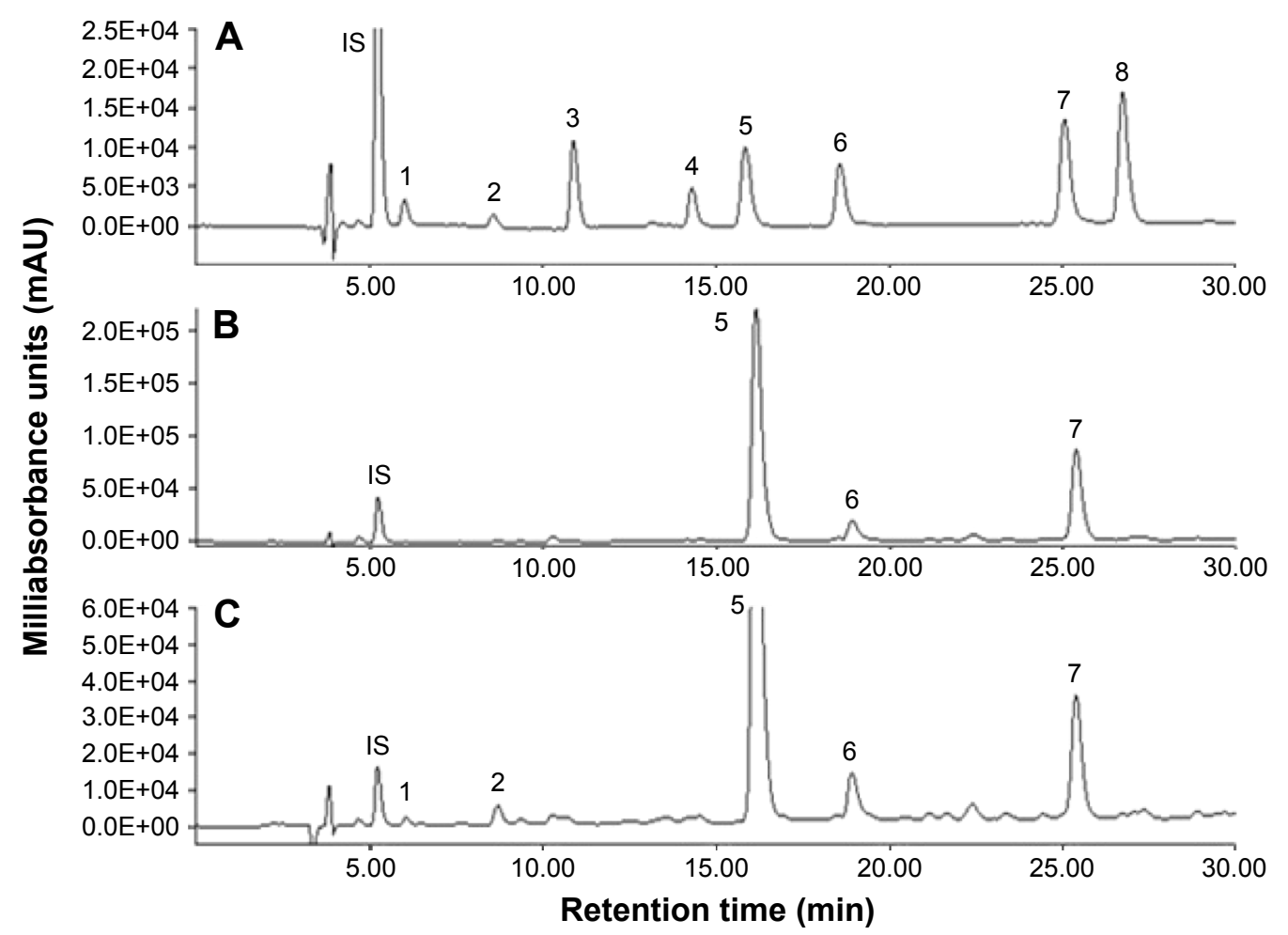

Figure 2 High-performance liquid chromatograms of catechin standards detected at $280 \mathrm{~nm}(\mathbf{A})$ and green tea leaf waste extract at $280 \mathrm{~nm}(\mathbf{B})$ as well as $245 \mathrm{~nm}(\mathbf{C})$. Notes: Peaks: I, GC; 2, EGC; 3, C; 4, EC; 5, EGCG; 6, GCG; 7, ECG; 8, CG; internal standard (L-tryptophan).

Abbreviations: GC, gallocatechin; EGC, epigallocatechin; C, catechin; EC, epicatechin; EGCG, epigallocatechin gallate; GCG, gallocatechin gallate; ECG, epicatechin gallate; CG, catechin gallate; IS, internal standard; min, minutes. 
Table I Retention time $\left(t_{\mathrm{R}}\right)$, retention factor $(\kappa)$, separation factor $(\alpha)$, peak purity, and contents of catechins in green tea leaf waste extract

\begin{tabular}{lllllll}
\hline Peak number & Compound & $\boldsymbol{t}_{\mathrm{R}}(\mathbf{m i n})$ & $\boldsymbol{\kappa}$ & $\alpha$ & Peak purity $(\%)^{\text {Contents }(\mu \mathrm{g} / \mathbf{g})^{\mathrm{b}}}$ \\
\hline $\mathrm{I}$ & Gallocatechin (GC) & 6.00 & 0.67 & $2.06(\mathrm{I}, 2)^{\mathrm{a}}$ & 98.3 & $73.73 \pm 2.64$ \\
2 & Epigallocatechin (EGC) & 8.57 & 1.38 & $2.06(1,2)^{\mathrm{a}}$ & 99.4 & $267.50 \pm 1.91$ \\
5 & Epigallocatechin gallate (EGCG) & 15.82 & 3.39 & $2.46(2,5)^{\mathrm{a}}$ & 90.4 & $7,864.48 \pm 8.38$ \\
6 & Gallocatechin gallate (GCG) & 18.53 & 4.15 & $1.22(5,6)^{\mathrm{a}}$ & 99.1 & $496.29 \pm 2.25$ \\
7 & Epicatechin gallate (ECG) & 25.02 & 5.95 & $1.43(6,7)^{\mathrm{a}}$ & 98.9 & $1,917.93 \pm 10.43$ \\
\hline
\end{tabular}

Note: ${ }^{a}$ Numbers in parentheses represent values between two neighboring peaks. ${ }^{b}$ Data expressed as mean \pm standard deviation.

$0.2 \%$ phosphoric acid in water/tetrahydrofuran/acetonitrile to separate eight catechins within 50 minutes. Similarly, Chen et al ${ }^{12}$ used a C18 column $(250 \times 4.6 \mathrm{~mm}$ ID, $5 \mu \mathrm{m}$ particle size) and a binary mobile phase of $0.1 \%$ phosphoric acid in water/acetonitrile to separate six catechins within 45 minutes. In addition, a total of seven catechins were separated within 70 minutes by a gradient mobile phase of $20 \mathrm{mM} \mathrm{KH}_{2} \mathrm{PO}_{4} /$ acetonitrile. ${ }^{27}$ Obviously, all these methods had a major drawback of prolonged separation time. Comparatively, our method demonstrated a much shorter retention time in separation of eight catechins standards and five catechins in green tea leaf waste. Table 2 shows the identification data of catechins in green tea leaf waste. On the basis of the identification criteria described previously, five catechins including GC, EGC, EGCG, GCG, and ECG were present in green tea leaf waste.

\section{Method validation}

The quality control data of catechins in green tea leaf waste by HPLC are shown in Table 3. The relative standard deviation (RSD) values of intraday variability for GC, EGC, EGCG, GCG, and ECG were $6.5 \%, 7.9 \%, 1.5 \%, 4.6 \%$, and $2.5 \%$, respectively, whereas the RSD values of interday variability were $5.2 \%, 0.2 \%, 2.9 \%, 6.4 \%$, and $4.6 \%$, respectively, demonstrating a high reproducibility of this method. In several previous studies, Spacil et a ${ }^{28}$ determined GC, EGC, EGCG, GCG, and ECG in nonfermented tea Formosa Gunpowder by
HPLC, and the RSD of the intraday variability was shown to be from $5.09 \%$ to $7.09 \%$. Similarly, Rahim et $\mathrm{al}^{29}$ analyzed GC, EGC, EGCG, GCG, and ECG in green tea by HPLC, and the RSD of intraday and interday variabilities ranged from $1.78 \%$ to $2.53 \%$ and $1.47 \%$ to $2.53 \%$, respectively. Pelillo et $\mathrm{a}^{30}$ determined GC, EGC, EGCG, GCG, and ECG in green tea by HPLC, and the RSD values of the intra-day and inter-day variabilities ranged from $0.96 \%$ to $4.56 \%$ and $1.47 \%$ to $6.60 \%$, respectively. All these outcomes are similar to the finding in our study.

Both LOD and LOQ of catechins are also shown in Table 3. The LOD values of GC, EGC, EGCG, GCG, and ECG were $0.35 \mu \mathrm{g} / \mathrm{mL}, 0.6 \mu \mathrm{g} / \mathrm{mL}, 0.4 \mu \mathrm{g} / \mathrm{mL}, 0.4 \mu \mathrm{g} / \mathrm{mL}$, and $0.25 \mu \mathrm{g} / \mathrm{mL}$, respectively, while the LOQ values were $1.05 \mu \mathrm{g} / \mathrm{mL}, 1.8 \mu \mathrm{g} / \mathrm{mL}, 1.2 \mu \mathrm{g} / \mathrm{mL}, 1.2 \mu \mathrm{g} / \mathrm{mL}$, and $0.75 \mu \mathrm{g} / \mathrm{mL}$. In several previous reports, Bonoli et $\mathrm{al}^{31}$ analyzed GC, EGC, EGCG, GCG, and ECG in green tea by HPLC, and the LOD values were shown to be $0.166 \mu \mathrm{g} / \mathrm{mL}$, $0.385 \mu \mathrm{g} / \mathrm{mL}, 0.192 \mu \mathrm{g} / \mathrm{mL}, 0.084 \mu \mathrm{g} / \mathrm{mL}$, and $0.04 \mu \mathrm{g} / \mathrm{mL}$, respectively, which was lower than the results in our study, probably caused by difference in sensitivity of HPLC instruments. However, in a study dealing with determination of catechins in green tea by HPLC, Wang et al ${ }^{32}$ reported that the LOD values of GC, EGC, EGCG, GCG, and ECG were $0.46 \mu \mathrm{g} / \mathrm{mL}, 0.58 \mu \mathrm{g} / \mathrm{mL}, 0.51 \mu \mathrm{g} / \mathrm{mL}, 1.16 \mu \mathrm{g} / \mathrm{mL}$, and $0.27 \mu \mathrm{g} / \mathrm{mL}$, respectively, whereas the LOQ values were $1.53 \mu \mathrm{g} / \mathrm{mL}, 1.92 \mu \mathrm{g} / \mathrm{mL}, 1.70 \mu \mathrm{g} / \mathrm{mL}, 3.87 \mu \mathrm{g} / \mathrm{mL}$,

Table 2 Identification data of catechins in green tea leaf waste extract ${ }^{\mathrm{a}}$

\begin{tabular}{|c|c|c|c|c|c|c|c|c|c|}
\hline \multirow[t]{2}{*}{ Peak no } & \multirow[t]{2}{*}{ Compounds } & \multirow[t]{2}{*}{$t_{R}(\min )$} & \multirow[t]{2}{*}{ MW (g/mol) } & \multicolumn{3}{|l|}{$\lambda_{\max }$} & \multicolumn{3}{|c|}{$[\mathrm{M}-\mathrm{H}]^{-}(\mathrm{m} / \mathrm{z})^{\mathrm{b}}$} \\
\hline & & & & Extract & Standard & Reported & Extract & Standard & Reported \\
\hline 1 & Gallocatechin (GC) & 6.00 & 306 & 271 & 271 & $275,{ }^{,} 270^{d}$ & 305 & 305 & $305,{ }^{c} 305^{e}$ \\
\hline 2 & Epigallocatechin (EGC) & 8.57 & 306 & 271 & 271 & $272,{ }^{\mathrm{c}} 270^{\mathrm{d}}$ & 305 & 305 & $305^{\mathrm{c}} 305^{\mathrm{e}}$ \\
\hline 5 & Epigallocatechin gallate (EGCG) & 15.82 & 458 & 274 & 274 & $276,{ }^{\mathrm{c}} 275^{\mathrm{d}}$ & 457 & 457 & $457,{ }^{\mathrm{c}} 457^{\mathrm{e}}$ \\
\hline 6 & Gallocatechin gallate (GCG) & 18.53 & 458 & 274 & 274 & $276,^{\mathrm{c}} 275^{\mathrm{d}}$ & 457 & 457 & $457, c^{c} 457^{e}$ \\
\hline 7 & Epicatechin gallate (ECG) & 25.02 & 442 & 278 & 278 & $278,{ }^{\mathrm{c}} 275^{\mathrm{d}}$ & 441 & 441 & $44 I, c^{c} 44 I^{\mathrm{e}}$ \\
\hline
\end{tabular}

Notes: ${ }^{a} \mathrm{~A}$ gradient mobile phase of acetonitrile and $0.1 \%$ formic acid in water was used. ${ }^{\mathrm{b}}$ Determined by LC-MS. 'Based on the reference value in Lin et al. ${ }^{21}$ 'Based on the reference value in Wang et al. ${ }^{33}$ Based on the reference value in Wu et al. ${ }^{22}$

Abbreviations: MW, molecular weight; LC-MS, liquid chromatography-mass spectrometry; $\lambda_{\text {max }}$, absorption maximum; $t_{\mathrm{R}}$, retention time. 
Table 3 Quality control data of catechins in green tea leaf waste by HPLC

\begin{tabular}{|c|c|c|c|c|c|c|c|c|}
\hline \multirow[t]{2}{*}{ Compound } & \multirow{2}{*}{$\begin{array}{l}\text { LOD } \\
(\mu g / m L)\end{array}$} & \multirow{2}{*}{$\begin{array}{l}\text { LOQ } \\
(\mu g / m L)\end{array}$} & \multicolumn{2}{|l|}{ Recovery ${ }^{a}$} & \multicolumn{2}{|c|}{ Intraday variability } & \multicolumn{2}{|c|}{ Interday variability } \\
\hline & & & $\begin{array}{l}\text { Mean } \pm \text { SD } \\
\text { (\%) }\end{array}$ & $\begin{array}{l}\text { RSD }^{b} \\
\text { (\%) }\end{array}$ & $\begin{array}{l}\text { Mean } \pm \text { SD } \\
(\mathrm{mg} / \mathrm{g})\end{array}$ & $\begin{array}{l}\text { RSD }^{b} \\
\text { (\%) }\end{array}$ & $\begin{array}{l}\text { Mean } \pm \text { SD } \\
(\mathrm{mg} / \mathrm{g})\end{array}$ & $\begin{array}{l}\text { RSD }^{b} \\
\text { (\%) }\end{array}$ \\
\hline Gallocatechin (GC) & 0.35 & 1.05 & $95.11 \pm 4.29$ & 4.51 & $0.062 \pm 0.004$ & 6.5 & $0.055 \pm 0.003$ & 5.2 \\
\hline Epigallocatechin (EGC) & 0.6 & 1.8 & $104.98 \pm 3.32$ & 3.16 & $0.24 \pm 0.02$ & 7.9 & $0.23 \pm 0.0004$ & 0.2 \\
\hline Epigallocatechin gallate (EGCG) & 0.4 & 1.2 & $101.20 \pm 2.11$ & 2.08 & $8.72 \pm 0.13$ & 1.5 & $8.84 \pm 0.26$ & 2.9 \\
\hline Gallocatechin gallate (GCG) & 0.4 & 1.2 & $90.22 \pm 2.47$ & 2.74 & $0.46 \pm 0.02$ & 4.6 & $0.43 \pm 0.03$ & 6.4 \\
\hline Epicatechin gallate (ECG) & 0.25 & 0.75 & $101.43 \pm 0.68$ & 0.67 & $2.19 \pm 0.06$ & 2.5 & $2.21 \pm 0.10$ & 4.6 \\
\hline
\end{tabular}

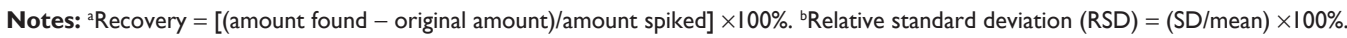

Abbreviations: HPLC, high-performance liquid chromatography; LOD, limit of detection; LOQ, limit of quantitation; SD, standard deviation.

and $0.92 \mu \mathrm{g} / \mathrm{mL}$, respectively. This outcome is similar to the finding in our study.

The recovery data of catechins are also shown in Table 3, with GC, EGC, EGCG, GCG, and ECG shown to be $95.1 \%$, $104.9 \%, 101.2 \%, 90.2 \%$, and $101.4 \%$, respectively. This outcome is similar to that reported by several other authors. For instance, Wang et $\mathrm{al}^{33}$ analyzed GC, EGC, EGCG, GCG, and ECG in Oo-long tea leaves by HPLC, and the recoveries were shown to be $98.56 \%, 99.46 \%, 99.73 \%, 99.28 \%$, and $98.45 \%$, respectively. Similarly, the recoveries of GC, EGC, EGCG, GCG, and ECG were reported to be $99.8 \%, 96.58 \%, 94.5 \%$, $91.25 \%$, and $88.96 \%$ in black tea leaves by HPLC analysis. ${ }^{34}$ Peng et $\mathrm{al}^{35}$ determined GC, EGC, EGCG, GCG, and ECG in green tea by HPLC, and the recoveries were found to be $85.6 \%, 101.06 \%, 92.56 \%, 103.86 \%$, and $103.04 \%$, respectively. All these outcomes are similar to the recovery in our study, demonstrating a high accuracy of our method.

\section{Quantitation of catechins in green tea leaf waste}

An internal standard L-tryptophan was used for quantitation. The regression equations used for quantitation of $\mathrm{GC}, \mathrm{EGC}, \mathrm{EGCG}, \mathrm{GCG}$, and ECG were $y=0.8257 x-0.0166$, $y=0.4366 x+0.1261, y=0.6735 x-0.4653, y=0.9711 x+0.0374$, and $y=0.9995 x+0.4243$, respectively, with the correlation coefficient $(R)$ being $>0.99$ for all. After quantitation, EGCG was found to be present in the most abundant amount $(7,864.48 \mu \mathrm{g} / \mathrm{g})$, followed by ECG $(1,917.93 \mu \mathrm{g} / \mathrm{g}), \mathrm{GCG}$ (496.29 $\mu \mathrm{g} / \mathrm{g})$, EGC (267.5 $\mu \mathrm{g} / \mathrm{g})$, and GC (73.73 $\mu \mathrm{g} / \mathrm{g})$. However, three catechins including catechin, CG, and EC remained undetected in green tea leaf waste.

\section{Catechin nanoemulsion characteristics}

Figure 3 shows particle size distribution of blank nanoemulsion (Figure $3 \mathrm{~A}$ ) as well as catechin nanoemulsion with
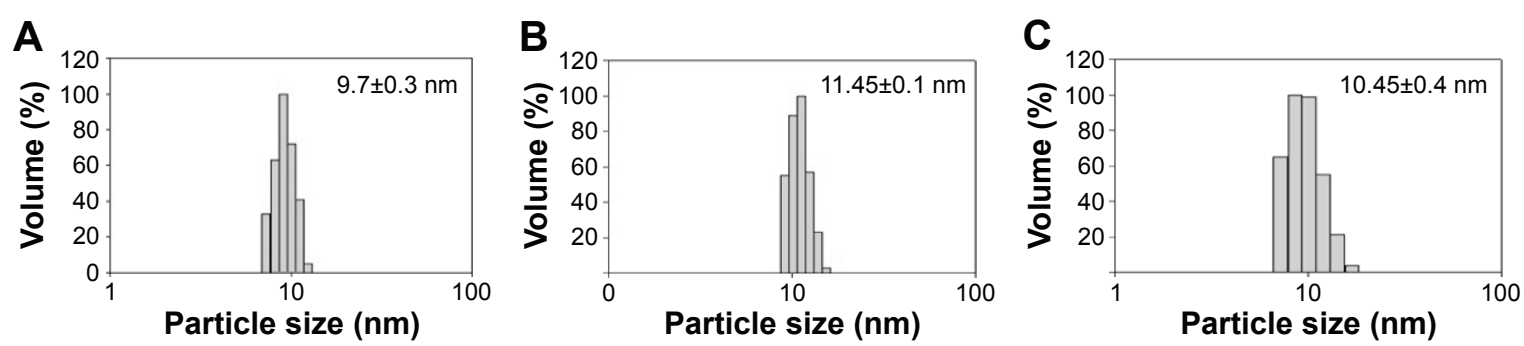
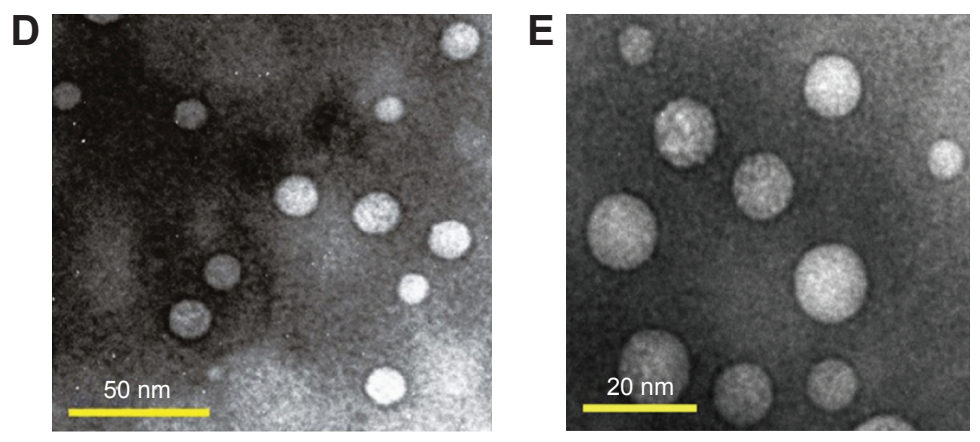

Figure 3 Particle size distribution of blank nanoemulsion $(\mathbf{A})$ as well as catechin nanoemulsion with filtration (B) and without filtration (C) along with TEM images of catechin nanoemulsion captured at two different magnifications ( $\mathbf{D}$ and $\mathbf{E}$ ).

Abbreviation: TEM, transmission electron microscope. 
filtration (Figure 3B) and without filtration through a $0.22 \mu \mathrm{m}$ membrane filter (Figure 3C), as determined by DLS, which equaled $9.7 \mathrm{~nm}, 11.45 \mathrm{~nm}$, and $10.45 \mathrm{~nm}$, respectively. This outcome clearly indicated that the average particle size of catechin nanoemulsion remained unaffected even without filtration through a $0.22 \mu \mathrm{m}$ membrane filter, demonstrating that a highly homogeneous nanoemulsion was successfully prepared. For TEM analysis, the average particle size was $13 \mathrm{~nm}$ with a spherical shape being observed (Figure 3D and E). Compared to many published reports, the average particle size of catechin nanoemulsion prepared in our laboratory was much smaller. For instance, Kim et $\mathrm{al}^{6}$ prepared catechin nanoemulsion composed of cholesterol, phytosterol, glycerol, and water, and the average particle size was determined to be $300 \mathrm{~nm}$ by DLS analysis. Similarly, Zou et al ${ }^{36}$ prepared EGCG nanoliposome with phospholipid, cholesterol, and Tween 80 as the main components, and the mean particle size was found to be $71.7 \mathrm{~nm}$ by DLS analysis. More recently, Gadkari and Balarman ${ }^{37}$ prepared catechin nanoemulsion consisting of sunflower oil, Tween 20, Tween 80, lecithin, and water, and the average particle size was shown to be $245 \mathrm{~nm}$ by DLS analysis. Srivastava et $\mathrm{al}^{38}$ prepared EGCG-PLGA nanoparticles containing PLGA, polyvinyl alcohol, and water, and the average particle size was found to be $127.2 \mathrm{~nm}$ by TEM analysis. Obviously, the difference in particle size distribution can be attributed to variety and amount of surfactants as well as method of preparation.

Zeta potential is a vital index of polydispersity. It has been well documented that a highly stable nanoemulsion can be achieved when the zeta potential is $>30 \mathrm{mv}$ or $<-30 \mathrm{mv}$ because of high electrostatic repulsion force between particles. ${ }^{39}$ In our experiment, the zeta potential of the nanoemulsion was $-66.3 \pm 1.1 \mathrm{mv}$, implying a much higher stability of this nanoemulsion when compared to many published reports. For example, Huang et $\mathrm{l}^{40}$ prepared catechin liposomes composed of Tween 80, Epikuron 200, and cholesterol with the zeta potential found to be $-16.5 \mathrm{mv}$. In a later study, Pace et $\mathrm{al}^{41}$ prepared EGCG nanoliposomes containing lecithin, cholesterol, and PBS buffer solution with the zeta potential found to be $-6.8 \mathrm{mv}$. Similarly, Srivastava et $\mathrm{al}^{38}$ prepared EGCG-PLGA nanoparticles with the zeta potential determined to be $-24.5 \mathrm{mv}$. Comparatively, all these results revealed a lower stability of catechin or EGCG nanoparticles than the catechin nanoemulsion prepared in our study, which can be attributed to the difference in variety and amount of surfactants, $\mathrm{pH}$ value, and method of preparation.

For stability study, the particle size of the catechin nanoemulsion was $11.4 \mathrm{~nm}, 10.9 \mathrm{~nm}, 11.8 \mathrm{~nm}$, and $11.2 \mathrm{~nm}$ after 0 day, 7 days, 60 days, and 120 days storage at $4^{\circ} \mathrm{C}$, respectively, with the polydispersity index (PDI) being $0.27,0.29,0.30$, and 0.29. Accordingly, the lower the PDI, the better the dispersity of nanoemulsion. In addition, the catechin content in the nanoemulsion only showed a minor change, as evident by a level of $868.2 \mu \mathrm{g} / \mathrm{mL}$ at day 0 and $847.1 \mu \mathrm{g} / \mathrm{mL}$ at day 120 . Similarly, the encapsulation efficiency of the catechin nanoemulsion after 0-day and 120day storage was $88.1 \%$ and $86.2 \%$, respectively. Similar outcome was reported by Chang and Chen, ${ }^{24}$ who prepared curcuminoid nanoemulsion with Tween 80 and water, and the average particle size was shown to be $11.5-12.3 \mathrm{~nm}$ over a 3-month storage period. In addition, the encapsulation efficiency of the catechin nanoemulsion prepared in our study was higher than that reported by $\mathrm{Hu}$ et $\mathrm{al}^{42}$ and Huang et al, ${ }^{40}$ as shown by a level of $81.7 \%$ of EGCG nanoparticles, and $65.8 \%-80.1 \%$ of catechin nanoparticles, respectively. Similarly, the PDI only showed a minor change over a 120 day storage period, demonstrating a highly stable catechin nanoemulsion prepared in our experiment. A similar result was found by Huang et al, ${ }^{40}$ Zou et al, ${ }^{36}$ Ponnuraj et al, ${ }^{43}$ and Pace et al, ${ }^{41}$ reporting the PDI to be $0.18,0.29,0.22$, and 0.24 , respectively, for catechin and EGCG nanoparticles.

\section{Dose effect of solvent and blank nanoemulsion on growth of PC-3 and CCD-986SK cells}

In our study, $50 \%$ ethanol solution was used for catechin extraction, and the blank was composed of lecithin, Tween 80 , and water. To avoid interference of these components on cell growth, the effect of $50 \%$ ethanol and blank nanoemulsion on growth of both CCD-986SK and PC-3 cells has been studied (Figure $4 \mathrm{~A}$ and $\mathrm{B}$ ). With the $50 \%$ ethanol dose at $0.25 \%-1 \%$, a high cell viability ( $>96.6 \%$ ) was shown for both PC-3 and CCD-986SK cells. However, by raising the $50 \%$ ethanol dose to $>2 \%$, the cell viability of PC-3 and CCD-986SK declined to $91.2 \%$ and $84.0 \%$, respectively (Figure $4 \mathrm{~A}$ ). Obviously, the higher the dose of $50 \%$ ethanol, the lower the cell viability of both PC-3 and CCD-986SK cells. A similar tendency was observed for the blank nanoemulsion, as evident by a high cell viability ( $>97 \%$ ) of both PC-3 and CCD-986SK when the dose was controlled at $0.08 \%-0.15 \%$ (Figure $4 \mathrm{~B}$ ). In several published reports, the ethanol dose was often controlled at $0.1 \%-1 \%$. For instance, Lippert et al ${ }^{44}$ studied the effect of endogenous estradiol metabolites on growth of breast cancer cells; the ethanol dose was controlled at $1 \%$ to avoid solvent interference. In a study dealing with the effect of brewed beer yeast ethanol extract on inhibition of lung 

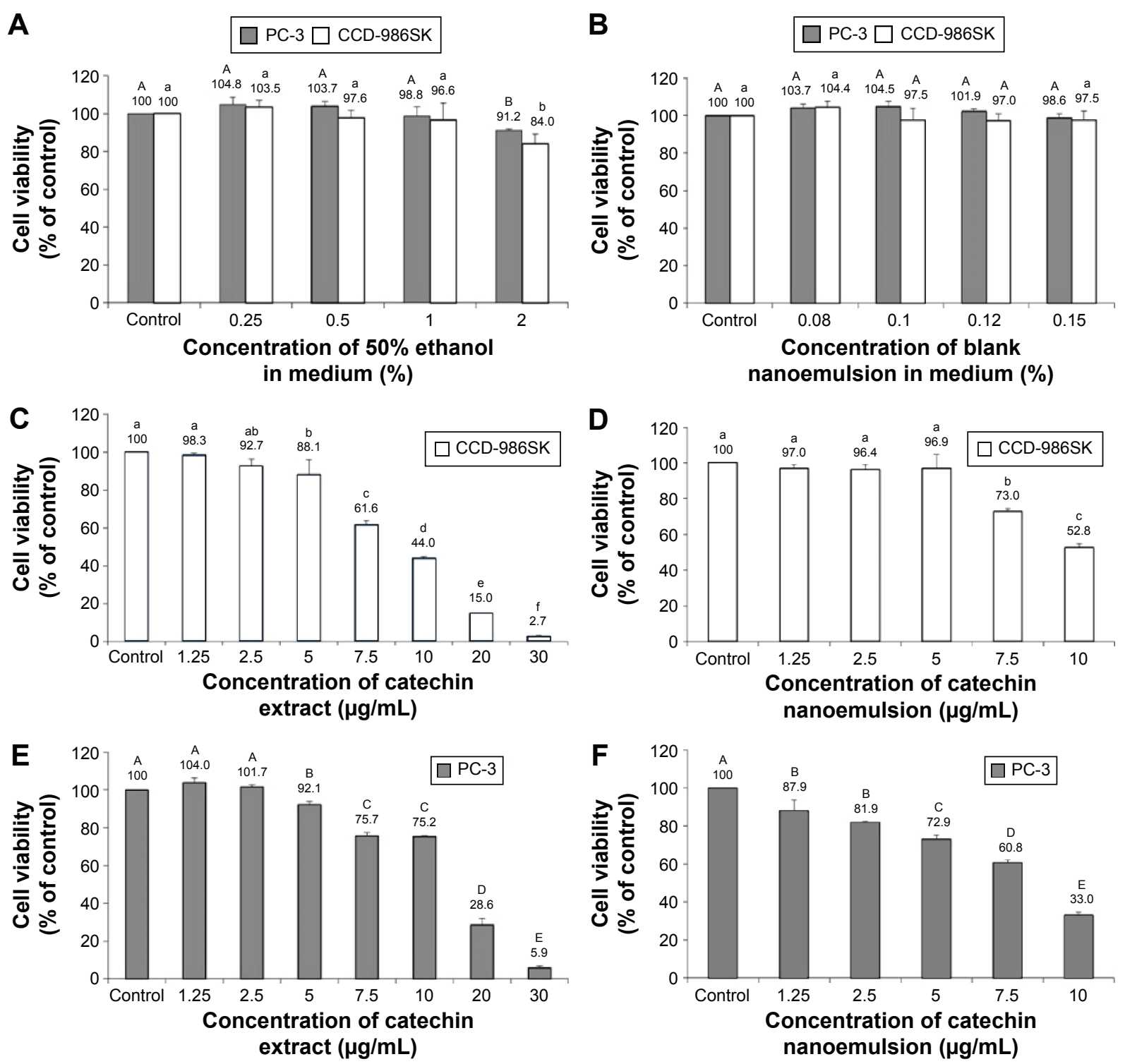

Figure 4 Effects of different levels of 50\% ethanol (A) and blank nanoemulsion (B) on the growth of both CCD-986SK fibroblast cells and PC-3 prostate cancer cells as well as the effects of catechin extract and nanoemulsion on CCD-986SK cells ( $\mathbf{C}$ and $\mathbf{D}$ ) and PC-3 cells (E and $\mathbf{F}$ ).

Notes: Results are presented as mean \pm standard deviation of triplicate analyses. Data with different capital letters $(A-E)$ on each bar in $(\mathbf{A})$, (B), (E), and (F) represent the PC-3 cell viability at different concentrations of ethanol, blank nanoemulsion, catechin extract, and catechin nanoemulsion and are significantly different at $P<0.05$ compared to the control, respectively. Data with different small letters ( $a-f)$ on each bar in (A), (B), (C), and (D) represent the CCD-986SK cell viability at different concentrations of ethanol, blank nanoemulsion, catechin extract, and catechin nanoemulsion and are significantly different at $P<0.05$ compared to the control, respectively.

cancer cells, $\operatorname{Lin}^{45}$ reported that a dose of $0.5 \%$ ethanol could maintain a high cell viability without solvent interference. In addition to solvent, $\mathrm{Li}$ et $\mathrm{al}^{46}$ pointed out that various surfactants could affect colon cancer cell (HT-29) growth, with Tween 20 being higher than lecithin. Furthermore, the cell viability of HT-29 could decrease to $43 \%$ following a rise of Tween 20 dose to $0.02 \%$. Schöler et $\mathrm{al}^{47}$ further compared the effect of nine surfactants on growth of macrophage cells and found: poloxamine $908>$ poloxamer 407 $>$ poloxamer $188>$ Solutol HS 15 $>$ Tween $80>$ Lipoid 75 $>$ sodium cholate $>$ sodium dodecyl sulfate $>$ cetylpyridinium chloride. Therefore, similar to ethanol, the variety and amount of surfactants have to be carefully controlled to avoid cell growth interference.

\section{Effect of catechin extract and nanoemulsion on growth of PC-3 and CCD-986SK cells}

The effects of catechin extract and nanoemulsion on growth of CCD-986SK cells are shown in Figure 4C and D, respectively. A dose-dependent decrease was shown for the cell viability after treatment of catechin extract or nanoemulsion 
for 72 hours. A high cell viability $(>92.7 \%)$ was found for the catechin extract dose at $<2.5 \mu \mathrm{g} / \mathrm{mL}$. However, by raising the catechin extract dose to $5 \mu \mathrm{g} / \mathrm{mL}, 7.5 \mu \mathrm{g} / \mathrm{mL}, 10 \mu \mathrm{g} / \mathrm{mL}$, $20 \mu \mathrm{g} / \mathrm{mL}$, and $30 \mu \mathrm{g} / \mathrm{mL}$, the cell viability declined to $88.1 \%, 61.6 \%, 44 \%, 15 \%$, and $2.7 \%$, respectively. Unlike catechin extract, a high cell viability $(>96.4 \%)$ was shown for the catechin nanoemulsion dose at $<5 \mu \mathrm{g} / \mathrm{mL}$. However, following an increase in the catechin nanoemulsion dose to $7.5 \mu \mathrm{g} / \mathrm{mL}$ and $10 \mu \mathrm{g} / \mathrm{mL}$, the cell viability decreased to $73 \%$ and $52.8 \%$, respectively. Comparatively, catechin nanoemulsion exhibited a lower toxicity toward CCD-986SK cells than catechin extract.

Figure 4E and $\mathrm{F}$ show the effect of catechin extract and nanoemulsion on growth of PC-3 cells, respectively. The cell viability followed a dose-dependent decline after treatment of catechin extract or nanoemulsion for 72 hours. With the catechin extract dose at $<2.5 \mu \mathrm{g} / \mathrm{mL}$, no significant decrease $(P>0.05)$ was shown for PC-3 cells. However, by raising the catechin extract dose to $5 \mu \mathrm{g} / \mathrm{mL}, 7.5 \mu \mathrm{g} / \mathrm{mL}, 10 \mu \mathrm{g} / \mathrm{mL}$, $20 \mu \mathrm{g} / \mathrm{mL}$, and $30 \mu \mathrm{g} / \mathrm{mL}$, the cell viability dropped to $92.1 \%$, $75.7 \%, 75.2 \%, 28.6 \%$, and 5.9\%, respectively. Similarly, after treatment of PC-3 cells with catechin nanoemulsion at $1.25 \mu \mathrm{g} / \mathrm{mL}, 2.5 \mu \mathrm{g} / \mathrm{mL}, 5 \mu \mathrm{g} / \mathrm{mL}, 7.5 \mu \mathrm{g} / \mathrm{mL}$, and $10 \mu \mathrm{g} / \mathrm{mL}$, the cell viability declined to $87.9 \%, 81.9 \%, 72.9 \%, 60.8 \%$, and $33 \%$, respectively. The $\mathrm{IC}_{50}$ of catechin extract and nanoemulsion was $15.4 \mu \mathrm{g} / \mathrm{mL}$ and $8.5 \mu \mathrm{g} / \mathrm{mL}$, respectively, demonstrating that the latter possessed a more pronounced inhibition efficiency toward growth of PC-3 tumor cells.

In many published reports, the EGCG standard, the most abundant catechin in green tea leaves, was used most often to study its effect on growth of prostate cancer cells PC-3 or LNCaP. For instance, Adhami et $\mathrm{al}^{48}$ studied the effect of EGCG $(10-40 \mu \mathrm{M})$ on growth of PC-3 and LNCaP cells; a dose-dependent decrease was found for both cell lines, with EGCG showing a higher tumor cell growth inhibition toward LNCaP cells than PC-3 cells. Similarly, Albrecht et al ${ }^{49}$ studied the effect of EGCG on growth of PC-3 cells and observed a dose-dependent decline in cell viability, which equaled $63 \%$ and $46 \%$ when treated with $25 \mu \mathrm{M}$ and $50 \mu \mathrm{M}$, respectively, with the $\mathrm{IC}_{50}$ being $38.95 \mu \mathrm{M}$. Recently, Shabana et $\mathrm{al}^{50}$ studied the effect of EGCG $(30-100 \mu \mathrm{M})$ on growth of PC-3 and $\mathrm{LNCaP}$ cells, and the $\mathrm{IC}_{50}$ was determined to be $90 \mu \mathrm{M}$ and $45 \mu \mathrm{M}$, respectively. In a similar study dealing with the effect of EGCG (25-100 $\mu \mathrm{M})$ on growth inhibition of prostate cancer cells DU 145 and $\mathrm{HH} 870$, the $\mathrm{IC}_{50}$ was shown to be $88.6 \mu \mathrm{M}$ and $45.3 \mu \mathrm{M}$, respectively. ${ }^{51}$ Comparatively, in our study, the $\mathrm{IC}_{50}(15.4 \mu \mathrm{g} / \mathrm{mL}$ or $34.8 \mu \mathrm{M})$ of catechin extract in inhibiting PC-3 tumor cells was much lower, probably caused by the synergistic effect due to the presence of some other catechins including GC, EGC, GCG, and ECG, but except EGCG. A total amount of these four catechins $(2,755.45 \mu \mathrm{g} / \mathrm{g})$ should contribute greatly to the lower $\mathrm{IC}_{50}$ compared to the EGCG standard.

In addition to prostate cancer cells, the effect of green tea extract or EGCG on growth inhibition of some other types of cancer cells has been well documented. Carvalho et $\mathrm{al}^{5}$ studied the effect of green tea extract on growth inhibition of kidney cancer cells A-497 and 769-P; the $\mathrm{IC}_{50}$ was shown to be $54 \mu \mathrm{g} / \mathrm{mL}$ and $129 \mu \mathrm{g} / \mathrm{mL}$, respectively. The effect of green tea extract and EGCG on growth inhibition of breast cancer cells MDA-MB-231 was studied by Thangapazham et al, ${ }^{52}$ with the $\mathrm{IC}_{50}$ shown to be $40 \mu \mathrm{g} / \mathrm{mL}$ and $50 \mu \mathrm{g} / \mathrm{mL}$, respectively. This result clearly revealed that green tea extract possessed a better growth inhibition toward breast cancer cells than EGCG. In addition, many authors pointed out through preparation of catechin nanoparticles, the effective dose could be reduced while the stability and bioavailability of catechins could be greatly enhanced. For example, Shabana et al $^{50}$ prepared EGCG-chitosan nanoparticles and studied their effect on growth inhibition of prostate cancer cells $\mathrm{LNCaP}$ and PC-3; the $\mathrm{IC}_{50}$ was found to be $1 \mu \mathrm{M}$ and $4 \mu \mathrm{M}$, respectively, while the EGCG standard was $45 \mu \mathrm{M}$ and $90 \mu \mathrm{M}$. It was postulated that EGCG-chitosan nanoparticles could penetrate into cells through endocytosis more efficiently than EGCG standard. In a similar study dealing with the effect of EGCG nanoparticles and EGCG on growth of melanoma cells Mel 928, the $\mathrm{IC}_{50}$ was determined to be $7 \mu \mathrm{M}$ and $53 \mu \mathrm{M}$, respectively, ${ }^{53}$ demonstrating a better growth inhibition efficiency of the former. Pace et $\mathrm{al}^{41}$ further reported that EGCG nanoparticles possessed a better growth inhibition efficiency toward breast cancer cells MCF-7 than EGCG standard. All these outcomes are in agreement with the finding in our study.

\section{PC-3 cell cycle analysis}

On the basis of MTT result, three doses of catechin extract $(7.5 \mu \mathrm{g} / \mathrm{mL}, 10 \mu \mathrm{g} / \mathrm{mL}$, and $20 \mu \mathrm{g} / \mathrm{mL}$ ) and catechin nanoemulsion $(5 \mu \mathrm{g} / \mathrm{mL}, 7.5 \mu \mathrm{g} / \mathrm{mL}$, and $10 \mu \mathrm{g} / \mathrm{mL})$ were selected for cell cycle analysis. The proportions of different cell cycle phases of PC-3 are shown in Table 4. Compared to control, a slight increase in sub-G1 (\%) was shown following a rise in doses of both catechin extract and nanoemulsion. However, after treatment of catechin extracts at $7.5 \mu \mathrm{g} / \mathrm{mL}, 10 \mu \mathrm{g} / \mathrm{mL}$, and $20 \mu \mathrm{g} / \mathrm{mL}$ for 72 hours, the proportion of G0/G1 phase declined to $62.3 \%, 55.6 \%$, and $38.9 \%$, respectively. A similar trend was observed for the catechin nanoemulsion treatment, as shown by a decrease in the G0/G1 phase to $61.2 \%, 55.8 \%$, and $43.4 \%$ when treated with $5 \mu \mathrm{g} / \mathrm{mL}, 7.5 \mu \mathrm{g} / \mathrm{mL}$, and 
Table 4 Different phases of cell cycle of PC-3 cancer cell line as affected by catechin extracts and catechin nanoemulsions prepared from green tea leaf waste

\begin{tabular}{lllll}
\hline Treatment & Sub-GI (\%) & G0/G I (\%) & S (\%) & G2/M (\%) \\
\hline Control & $1.5 \pm 0.2^{\mathrm{C}}$ & $65.9 \pm 0.6^{\mathrm{A}}$ & $10.9 \pm 0.6^{\mathrm{E}}$ & $22 \pm 0.1^{\mathrm{C}}$ \\
E $7.5 \mu \mathrm{g} / \mathrm{mL}$ & $1.7 \pm 0.7^{\mathrm{BC}}$ & $62.3 \pm 0.1^{\mathrm{B}}$ & $13.5 \pm 0.6^{\mathrm{D}}$ & $22.9 \pm 1.0^{\mathrm{C}}$ \\
$\mathrm{E} 10 \mu \mathrm{g} / \mathrm{mL}$ & $2.4 \pm 0.1^{\mathrm{AB}}$ & $55.6 \pm 3.2^{\mathrm{C}}$ & $17.9 \pm 0.7^{\mathrm{B}}$ & $24.7 \pm 0.6^{\mathrm{C}}$ \\
$\mathrm{E} 20 \mu \mathrm{g} / \mathrm{mL}$ & $2.4 \pm 0.4^{\mathrm{AB}}$ & $38.9 \pm 0.6^{\mathrm{E}}$ & $22.8 \pm 0.6^{\mathrm{A}}$ & $35.8 \pm 2.2^{\mathrm{A}}$ \\
$\mathrm{N} 5 \mu \mathrm{g} / \mathrm{mL}$ & $2.7 \pm 0.1^{\mathrm{A}}$ & $61.2 \pm 0.4^{\mathrm{B}}$ & $15.7 \pm 0.2^{\mathrm{C}}$ & $20.9 \pm 0.4^{\mathrm{C}}$ \\
$\mathrm{N} 7.5 \mu \mathrm{g} / \mathrm{mL}$ & $2.7 \pm 0.4^{\mathrm{A}}$ & $55.8 \pm 1.1^{\mathrm{C}}$ & $17.9 \pm 0.2^{\mathrm{B}}$ & $24.2 \pm 1.5^{\mathrm{C}}$ \\
$\mathrm{N} 10 \mu \mathrm{g} / \mathrm{mL}$ & $3.2 \pm 0.4^{\mathrm{A}}$ & $43.4 \pm 0.7^{\mathrm{D}}$ & $23.2 \pm 1.3^{\mathrm{A}}$ & $30.9 \pm 1.1^{\mathrm{A}}$ \\
\hline
\end{tabular}

Notes: Data are presented as mean \pm standard deviation $(n=3)$. Data with different letters in the same column represent significantly different values at $P<0.05$. The single letter is the comparison between control and data, while in the double letter representation the first letter denotes comparison between control and data and the second letter represents the comparison among data corresponding to different extract/nanoemulsion doses.

Abbreviations: $\mathrm{E}$, catechin extracts; $\mathrm{N}$, catechin nanoemulsions.

$10 \mu \mathrm{g} / \mathrm{mL}$, respectively. Comparatively, at the same dose, catechin nanoemulsion could lead to a lower proportion of G0/G1 phase than catechin extract. Similar to sub-G1 phase, the $\mathrm{S}$ phase proportion followed a dose-dependent increase for both catechin extract and nanoemulsion. In addition, at the same dose, a higher proportion of S phase was found for catechin nanoemulsion than for catechin extract. But for $\mathrm{G} 2 / \mathrm{M}$ phase, no significant difference $(P>0.05)$ was shown between control and catechin extract $(7.5 \mu \mathrm{g} / \mathrm{mL}$ and $10 \mu \mathrm{g} / \mathrm{mL})$ or catechin nanoemulsion $(5 \mu \mathrm{g} / \mathrm{mL}$ and $7.5 \mu \mathrm{g} / \mathrm{mL})$. Instead, a pronounced rise in $\mathrm{G} 2 / \mathrm{M}$ proportion occurred at a high dose of catechin extract $(20 \mu \mathrm{g} / \mathrm{mL})$ and nanoemulsion $(10 \mu \mathrm{g} / \mathrm{mL})$, which amounted to $35.8 \%$ and $30.9 \%$, respectively. Taken together, both catechin extract and nanoemulsion could lead to an arrest of PC-3 cells at S phase.

Similar outcomes were reported by several other authors. For example, Zhao et $\mathrm{al}^{54}$ pointed out that the cell cycle of stomach cancer cells SGC-7901 was arrested at S phase following treatment with $500 \mu \mathrm{g} / \mathrm{mL}$ of green tea or Pur tea extract. Shabana et al ${ }^{50}$ also illustrated that after treatment with $100 \mu \mathrm{M}$ EGCG or $6 \mu \mathrm{M}$ EGCG-chitosan nanoparticles for 48 hours, the cell cycle of prostate cancer cells PC-3 was arrested at $\mathrm{S}$ phase. However, in contrast to the result shown previously, Thakur et $\mathrm{al}^{55}$ reported that both prostate cancer cells $\mathrm{LNCaP}$ and PC-3 were arrested at $\mathrm{G} 0 / \mathrm{G} 1$ when treated with $10-80 \mu \mathrm{g} / \mathrm{mL}$ of tea polyphenol. Siddiqui et a ${ }^{53}$ further reported that after treatment of melanoma cells $\mathrm{Mel}$ 928 with EGCG $(40 \mu \mathrm{M})$ and EGCG nanoparticles $(4 \mu \mathrm{M})$ for 24 hours, the cell cycle was arrested at G2/M phase. Obviously, the difference in arrest of cell cycle phase can be attributed to various cancer cells and difference in concentration, incubation time as well as method of catechin preparation.

\section{PC-3 cell apoptosis analysis}

Table 5 shows the effect of catechin extract and nanoemulsion on apoptosis of PC-3 cells as determined by an Annexin/ PI assay. A dose-dependent increase in early apoptosis cells (B4) and late apoptosis cells (B2) was shown for the catechin nanoemulsion treatment, which equaled $18.7 \%$ and $7.9 \%$ at $10 \mu \mathrm{g} / \mathrm{mL}$, respectively. However, for the catechin extract treatment, there was no significant difference $(P>0.05)$ in early apoptosis cells among the various doses. Interestingly, a high proportion (13\%) of late apoptosis cells was found for the catechin extract treatment at $20 \mu \mathrm{g} / \mathrm{mL}$. By comparison, at the same dose, catechin nanoemulsion showed a higher proportion of both early and late apoptosis cells than that of catechin extract. But for necrosis cells, no significant difference $(P>0.05)$ was shown for the catechin nanoemulsion treatment among the various doses, while a higher proportion $(5.5 \%)$ occurred for the catechin extract treatment at $20 \mu \mathrm{g} / \mathrm{mL}$. Obviously, both catechin extract and nanoemulsion treatments could result in a higher proportion of PC-3 cells undergoing early apoptosis than late apoptosis or necrosis, with the dose being a vital factor in affecting apoptosis or necrosis.

In several other studies, On-Ki et al ${ }^{56}$ reported that the proportion of both early and late apoptosis cells was raised to $9.7 \%$ and $24.1 \%$, respectively, after treatment of prostate cancer cells DU 145 with Oo-Long tea polyphenol extract at $24 \mu \mathrm{g} / \mathrm{mL}$ for 48 hours. Similarly, after treatment of stomach cancer cells SG-7901 with $125 \mu \mathrm{g} / \mathrm{mL}$ of green tea, black tea, or Pur tea extracts, or $50 \mu \mathrm{g} / \mathrm{mL}$ of catechin for 48 hours, the proportions of early apoptosis cells rose to $10.4 \%, 5.9 \%, 3.9 \%$, and $12.6 \%$, respectively, while the late apoptosis cells increased to $5.7 \%, 4.4 \%, 2.0 \%$, and $8.3 \%$, respectively. ${ }^{54}$ Prasad et a ${ }^{18}$ further reported that the

Table 5 Apoptosis of PC-3 cancer cell line as affected by catechin extracts and catechin nanoemulsions

\begin{tabular}{lllll}
\hline Treatment & B I (\%) & B2 (\%) & B3 (\%) & B4 (\%) \\
\hline Control & $0.5 \pm 0.0^{\mathrm{C}}$ & $2.1^{\mathrm{I}} \pm 0 . \mathrm{I}^{\mathrm{D}}$ & $92.0 \pm 0.3^{\mathrm{A}}$ & $5.5 \pm 0.4^{\mathrm{D}}$ \\
$\mathrm{E} 7.5 \mu \mathrm{g} / \mathrm{mL}$ & $0.5 \pm 0.1^{\mathrm{C}}$ & $3.5 \pm 0.2^{\mathrm{D}}$ & $87.2 \pm 0.6^{\mathrm{B}}$ & $9.0 \pm 0.9^{\mathrm{C}}$ \\
$\mathrm{E} 10 \mu \mathrm{g} / \mathrm{mL}$ & $0.5 \pm 0.1^{\mathrm{C}}$ & $3.4 \pm 0.1^{\mathrm{D}}$ & $86.4 \pm 1.8^{\mathrm{B}}$ & $9.7 \pm 1.7^{\mathrm{C}}$ \\
$\mathrm{E} 20 \mu \mathrm{g} / \mathrm{mL}$ & $5.5 \pm 0.1^{\mathrm{A}}$ & $13.0 \pm 1.7^{\mathrm{A}}$ & $73.5 \pm 3.0^{\mathrm{D}}$ & $8.2 \pm 1.3^{\mathrm{C}}$ \\
$\mathrm{N} 5 \mu \mathrm{g} / \mathrm{mL}$ & $0.9 \pm 0.1^{\mathrm{BC}}$ & $3.4 \pm 0.6^{\mathrm{D}}$ & $86.3 \pm 1.3^{\mathrm{B}}$ & $9.5 \pm 0.6^{\mathrm{C}}$ \\
$\mathrm{N} 7.5 \mu \mathrm{g} / \mathrm{mL}$ & $1.1 \pm 0.1^{\mathrm{B}}$ & $5.6 \pm 0.1^{\mathrm{C}}$ & $79.8 \pm 0.4^{\mathrm{C}}$ & $13.6 \pm 0.6^{\mathrm{B}}$ \\
$\mathrm{N} 10 \mu \mathrm{g} / \mathrm{mL}$ & $1.2 \pm 0.1^{\mathrm{B}}$ & $7.9 \pm 1.1^{\mathrm{B}}$ & $72.3 \pm 1.3^{\mathrm{D}}$ & $18.7 \pm 0.1^{\mathrm{A}}$ \\
\hline
\end{tabular}

Notes: Data are presented as mean \pm standard deviation $(n=3)$. Data with different letters in the same column represent significantly different values at $P<0.05$. The single letter is the comparison between control and data, while in the double letter representation the first letter denotes comparison between control and data and the second letter represents the comparison among data corresponding to different extract/nanoemulsion doses. For control, cells were incubated in medium only. Quantitative analysis of viable cells (B3), early apoptosis cells (B4), late apoptosis cells (B2), and necrosis cells (BI).

Abbreviations: $\mathrm{N}$, catechin nanoemulsions; $\mathrm{E}$, catechin extract. 
proportion of late apoptosis cells could be raised to $51.7 \%$ $61.4 \%$ after treatment of prostate cancer cells PC-3 with black tea teaflavin $(40-80 \mu \mathrm{g} / \mathrm{mL})$ for 48 hours. In a study dealing with the effect of EGCG $(0-80 \mu \mathrm{g} / \mathrm{mL})$ on apoptosis of bladder cancer cells TP 24, a dose-dependent increase in cell apoptosis was shown, with the proportions of early and late apoptosis cells being $13.1 \%$ and $26 \%$, respectively. Apparently, catechin can induce apoptosis of various types of cancer cells, with the inhibition efficiency being dependent upon cell variety and dose. In addition to catechin extract, the effect of catechin nanoparticles on cancer cell apoptosis has been well documented. Siddiqui et $\mathrm{al}^{53}$ studied the effect of EGCG $(2.74 \mu \mathrm{mol} / \mathrm{L}$ and $40 \mu \mathrm{mol} / \mathrm{L})$ and PLA-PEG-EGCG nanoparticles $(1.37 \mu \mathrm{mol} / \mathrm{L}$ and $2.74 \mu \mathrm{mol} / \mathrm{L})$ on apoptosis of prostate cancer cells PC-3; the proportions of apoptosis cells were raised to $5.5 \%$ and $72.9 \%$, respectively, for the former, as well as $5.4 \%$ and $71.8 \%$, for the latter. Recently, Chen et $\mathrm{al}^{57}$ pointed out the proportions of early and late apoptosis cells increased to $3.2 \%$ and $12.6 \%$, respectively, after treatment of melanoma cells B16F10 with EGCG for 48 hours. However, following the EGCG nanoparticle treatment, the proportions could further rise to $6.5 \%$ and $20.9 \%$, respectively. This finding further demonstrated that catechin nanoparticles could induce a higher proportion of cell apoptosis than catechin extract or EGCG standard.

\section{Protein expression associated with cell cycle and apoptosis}

Based on the result of cell cycle analysis, both catechin extract and nanoemulsion could lead to an arrest of PC-3 cells at $\mathrm{S}$ phase. Thus, the expression of proteins associated with regulation of cell cycle such as cyclin A and cyclin B, CDKs such as CDK1 and CDK2, CDKs inhibitors such as P27, as well as the expression of proteins associated with apoptosis such as bcl-2 and cytochrome $\mathrm{C}$ have been investigated.

Figure 5A shows the effect of catechin extract and nanoemulsion on P27 expression in PC-3 cells. A dose-dependent rise in $\mathrm{P} 27$ expression was shown for both catechin extract and nanoemulsion. However, at the same dose, a much higher P27 expression was found for catechin nanoemulsion than for catechin extract, implying that the former could inhibit the activity of cyclin E/cyclin A-CDK2 complex more
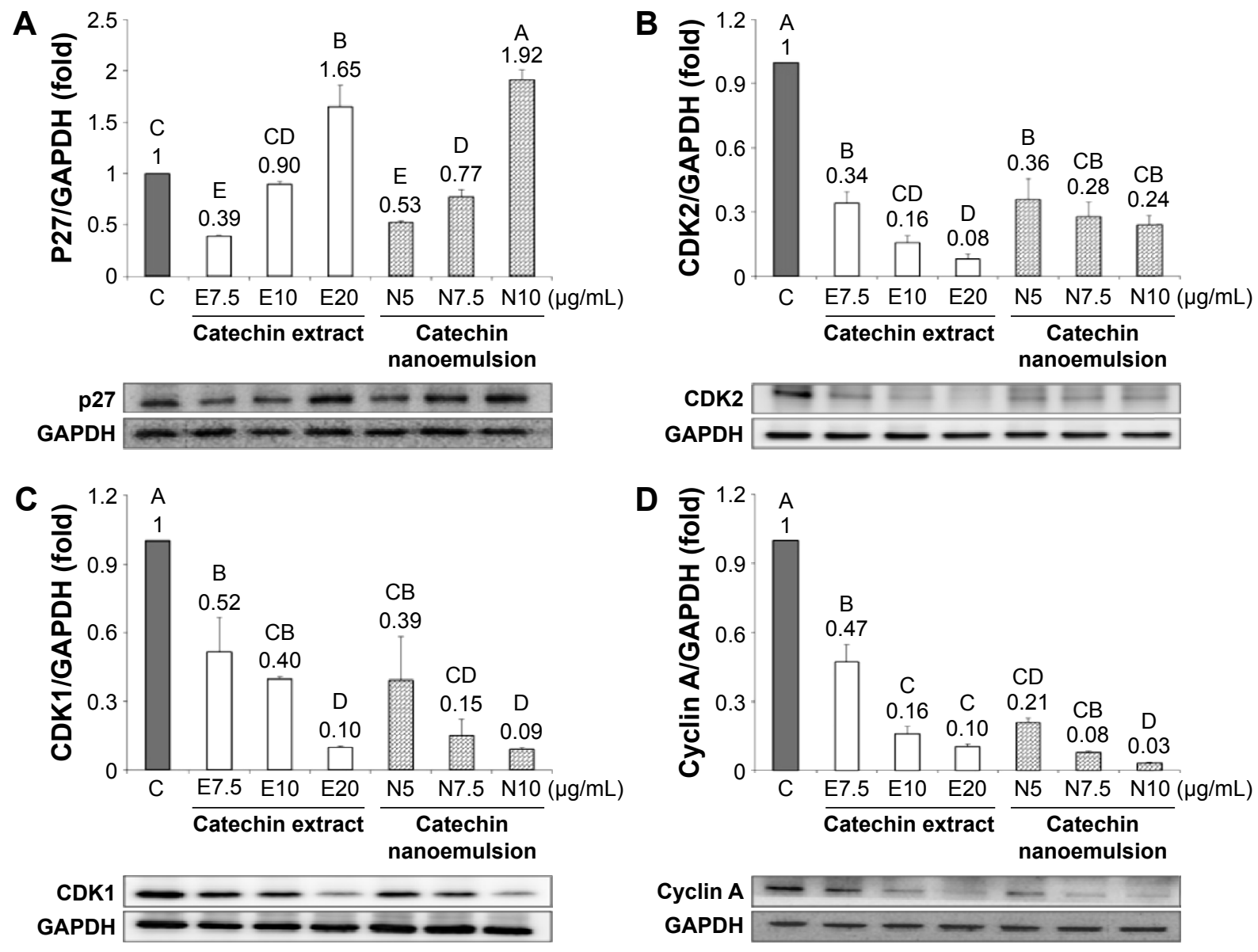

Figure 5 (Continued) 

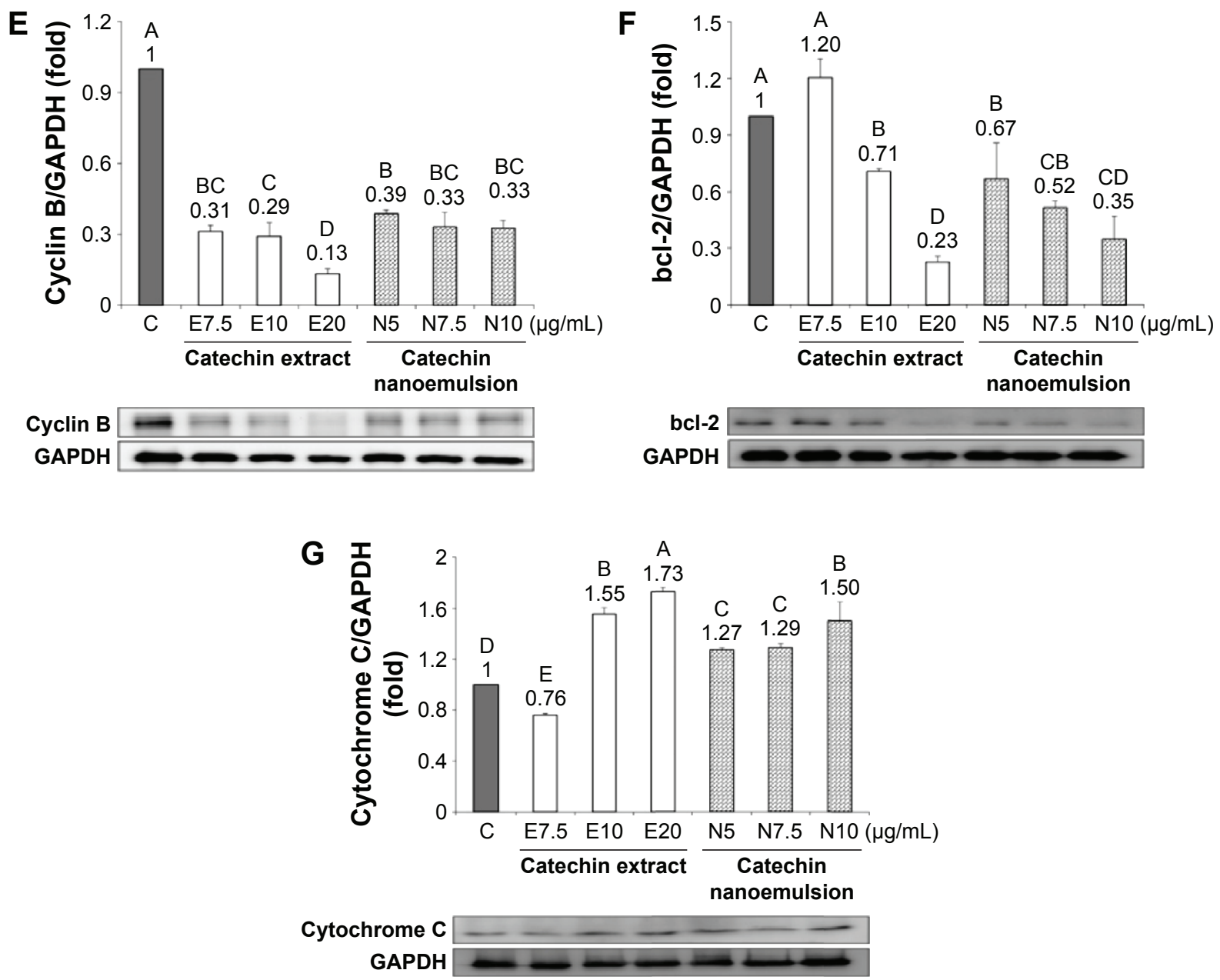

Figure 5 Effects of catechin extract and nanoemulsion on P27 (A), CDK2 (B), CDKI (C), cyclin A (D), cyclin B (E), bcl-2 (F), and cytochrome C (G) protein expressions in PC-3 prostate cancer cells.

Notes: Results are presented as mean \pm standard deviation of triplicate analyses. Data with different capital letters (A-E) on each bar represent the ratio of each protein expression relative to GAPDH at different concentrations of catechin extract or nanoemulsion and are significantly different at $P<0.05$ compared to the control. The abbreviations used in $X$-axes indicate control $(C)$, catechin extract $(E)$, and catechin nanoemulsion $(N)$.

Abbreviations: CDK, cyclin-dependent kinase; bcl-2, B-cell lymphoma 2; GAPDH, glyceraldehyde 3-phosphate dehydrogenase.

effectively than catechin extract, resulting in an arrest of PC-3 cell cycle at S phase. Similar findings were reported by several other authors. For instance, Gupta et al ${ }^{58}$ pointed out that the P27 expression in prostate cancer cells LNCaP and DU 145 could be enhanced after treatment with EGCG. Peng et $\mathrm{a}^{59}$ also found that after treatment with cocoa tea extract $(44-66 \mu \mathrm{M})$ for 72 hours, the P27 expression in prostate cancer cells PC-3 rose by 1.5-2.5-fold, but the cell cycle was arrested as $\mathrm{G} 2 / \mathrm{M}$ phase. In a recent study, Shabana et $\mathrm{al}^{50}$ studied the effect of EGCG $(100 \mu \mathrm{M})$ and EGCG-chitosan nanoparticles $(6 \mu \mathrm{M})$ on P27 expression in PC-3 cells for 48 hours; the P27 expression was raised by 1.5- and 3.3-fold, respectively, with the cell cycle arrested at $\mathrm{S}$ phase.

As the activation of P27 can inhibit the expression of CDKs and both CDK1 and CDK2 are associated with $\mathrm{S}$ phase, the expressions of CDKs and their corresponding cyclins need to be further investigated. The effect of catechin extract and nanoemulsion on expressions of CDK2 and CDK1 is shown in Figure 5B and C, respectively. A dose-dependent decline in CDK1 and CDK2 expressions was shown for both catechin extract and nanoemulsion treatments. After treatment of PC-3 cells with $7.5 \mu \mathrm{g} / \mathrm{mL}$, $10 \mu \mathrm{g} / \mathrm{mL}$, and $20 \mu \mathrm{g} / \mathrm{mL}$ of catechin extract, the CDK2 expression declined by $0.34-, 0.16-$, and 0.08 -fold, respectively. However, following treatment with $5 \mu \mathrm{g} / \mathrm{mL}$, $7.5 \mu \mathrm{g} / \mathrm{mL}$, and $10 \mu \mathrm{g} / \mathrm{mL}$ of catechin nanoemulsion, the CDK2 expression dropped by 0.36-, 0.28-, and 0.24-fold, respectively (Figure 5B). Comparatively, at the same dose $(7.5 \mu \mathrm{g} / \mathrm{mL}$ or $10 \mu \mathrm{g} / \mathrm{mL})$, there was no significant difference $(P>0.05)$ in CDK2 expression in PC-3 cells between catechin extract and nanoemulsion. However, a different trend was observed for CDK1 expression (Figure 5C), which declined 
by $0.52-, 0.4-$, and 0.1 -fold, respectively, after treatment of $7.5 \mu \mathrm{g} / \mathrm{mL}, 10 \mu \mathrm{g} / \mathrm{mL}$ and $20 \mu \mathrm{g} / \mathrm{mL}$ of catechin extract. However, following treatment of $5 \mu \mathrm{g} / \mathrm{mL}, 7.5 \mu \mathrm{g} / \mathrm{mL}$, and $10 \mu \mathrm{g} / \mathrm{mL}$ of catechin nanoemulsion, the CDK1 expression diminished by 0.39-, 0.15-, and 0.09-fold, respectively. By comparison, at the same dose of $7.5 \mu \mathrm{g} / \mathrm{mL}$ or $10 \mu \mathrm{g} / \mathrm{mL}$, the decline in CDK1 expression in PC-3 cells was larger for catechin nanoemulsion than for catechin extract.

Figure 5D and $\mathrm{E}$ shows the effect of catechin extract and nanoemulsion on expressions of cyclin $\mathrm{A}$ and cyclin $\mathrm{B}$ in PC-3 cells, respectively. Both expressions of cyclin A and cyclin $\mathrm{B}$ followed a dose-dependent decrease. After treatment of PC-3 cells with $7.5 \mu \mathrm{g} / \mathrm{mL}, 10 \mu \mathrm{g} / \mathrm{mL}$, and $20 \mu \mathrm{g} / \mathrm{mL}$ of catechin extract for 72 hours, the cyclin A expression declined by $0.47-, 0.16-$, and 0.1 -fold, respectively, while the cyclin B expression dropped by 0.31-, 0.29-, and 0.13-fold. Similarly, following treatment of PC-3 cells with $5 \mu \mathrm{g} / \mathrm{mL}$, $7.5 \mu \mathrm{g} / \mathrm{mL}$, and $10 \mu \mathrm{g} / \mathrm{mL}$ of catechin nanoemulsion for 72 hours, the cyclin A expression diminished by 0.21-, 0.08-, and 0.03-fold, respectively, whereas the cyclin B expression lowered by 0.39 -, 0.33 -, and 0.33 -fold. Comparatively, at the same dose of $7.5 \mu \mathrm{g} / \mathrm{mL}$ or $10 \mu \mathrm{g} / \mathrm{mL}$, the decrease in cyclin A expression was much higher for catechin nanoemulsion than for catechin extract. However, for cyclin B expression, no significant difference $(P>0.05)$ was shown between catechin extract and nanoemulsion at the same dose $(7.5 \mu \mathrm{g} / \mathrm{mL}$ or $10 \mu \mathrm{g} / \mathrm{mL})$.

Similar results were reported by several other authors. Thangapazham et $\mathrm{al}^{52}$ studied the effect of green tea polyphenol and EGCG on expression of protein-associated breast cancer cell cycle and reported that the expressions of cyclin A, cyclin B, CDK2, and CDK1 followed a pronounced decline after 24 hours treatment. Similarly, Lim and Cha ${ }^{60}$ studied the effect of EGCG on apoptosis of human anaplastic thyroid cancer cells and found that the expressions of cyclin A, cyclin B, and CDK1 decreased significantly after 72 hours treatment. Singh and Katiyar ${ }^{61}$ further pointed out that after treatment of human skin cancer cells A431 and SCC13 with EGCG for 48 hours, the CDK2 expression was inhibited. The same phenomenon was observed in a study dealing with apoptosis of prostate cancer cells LNCaP and PC-3 as affected by EGCG and EGCG-chitosan nanoparticles. ${ }^{50}$ In addition, both expressions of cyclin $\mathrm{A}$ and cyclin B showed a declined trend after treatment of melanoma cells with EGCG and EGCG nanoparticles. ${ }^{53}$

As cell apoptosis may be associated with the mitochondria pathway, we further explored the effect of catechin extract and nanoemulsion on bcl-2 and cytochrome $\mathrm{C}$ expressions, both of which are shown in Figure $5 \mathrm{~F}$ and $\mathrm{G}$, respectively. No significant difference $(P>0.05)$ in bcl-2 expression was shown between control and catechin extract treatment $(7.5 \mu \mathrm{g} / \mathrm{mL})$. However, after treatment of $10 \mu \mathrm{g} /$ $\mathrm{mL}$ and $20 \mu \mathrm{g} / \mathrm{mL}$ of catechin extract as well as $5 \mu \mathrm{g} / \mathrm{mL}$, $7.5 \mu \mathrm{g} / \mathrm{mL}$, and $10 \mu \mathrm{g} / \mathrm{mL}$ of catechin nanoemulsion for 72 hours, the bcl-2 expression declined by 0.71 -, 0.23-, 0.67-, 0.52 -, and 0.35-fold, respectively (Figure 5F). This outcome revealed that catechin nanoemulsion possessed a higher inhibition efficiency toward bcl-2 expression than catechin extract at the same dose. As bcl-2 is an antiapoptotic protein, the inhibition of bcl-2 expression can lead to PC-3 cell apoptosis. For cytochrome $\mathrm{C}$, the expression followed a dosedependent increase (Figure 5G). Following treatment of PC-3 cells with $10 \mu \mathrm{g} / \mathrm{mL}$ and $20 \mu \mathrm{g} / \mathrm{mL}$ of catechin extract, the cytochrome $\mathrm{C}$ expression rose by 1.55 - and 1.73 -fold, respectively. However, an increase by 1.27-, 1.29-, and 1.5-fold was observed for the catechin nanoemulsion treatment at $5 \mu \mathrm{g} / \mathrm{mL}$, $7.5 \mu \mathrm{g} / \mathrm{mL}$, and $10 \mu \mathrm{g} / \mathrm{mL}$, respectively. Comparatively, the cytochrome $\mathrm{C}$ expression was higher for the nanoemulsion treatment than for the extract treatment at the same dose $(7.5 \mu \mathrm{g} / \mathrm{mL})$. Interestingly, at $10 \mu \mathrm{g} / \mathrm{mL}$, there was no significant difference $(P>0.05)$ in cytochrome $\mathrm{C}$ expression between catechin nanoemulsion and extract. This phenomenon indicated that both catechin extract and nanoemulsion could induce apoptosis of PC-3 cells through cytochrome $\mathrm{C}$ release into cytoplasm for conjugation with Apaf-1 to activate procaspase-9 for subsequent apoptosome complex formation and then caspase- 3 activation for cell apoptosis. ${ }^{24}$

The activities of caspase-3, caspase- 8 , and caspase- 9 in PC -3 cells as affected by catechin extract and nanoemulsion are shown in Figure 6. No significant difference $(P>0.05)$ in caspase- 3 activity was shown between control and catechin extract at $7.5 \mu \mathrm{g} / \mathrm{mL}$ or $10 \mu \mathrm{g} / \mathrm{mL}$. However, a slight increase in caspase-3 activity by 1.2-fold was observed for catechin extract at a higher dose of $20 \mu \mathrm{g} / \mathrm{mL}$. Similarly, for catechin nanoemulsion, only the doses of $7.5 \mu \mathrm{g} / \mathrm{mL}$ and $10 \mu \mathrm{g} / \mathrm{mL}$ showed a significantly higher $(P<0.05)$ caspase-3 activity than control by 1.1 - and 1.2-fold, respectively. Similar outcome occurred for activities of caspase- 8 and caspase- 9 . Following the catechin extract treatment at $10 \mu \mathrm{g} / \mathrm{mL}$ and $20 \mu \mathrm{g} / \mathrm{mL}$, the caspase- 8 activity was significantly higher $(P<0.05)$ than control by 1.15 - and 1.2 -fold, respectively, as were activities of 1.2- and 1.22-fold higher for the catechin nanoemulsion treatment at $7.5 \mu \mathrm{g} / \mathrm{mL}$ and $10 \mu \mathrm{g} / \mathrm{mL}$, respectively. But for caspase- 9 activity, only the dose $(20 \mu \mathrm{g} / \mathrm{mL})$ of catechin extract showed a significantly higher $(P<0.05)$ activity than control, while all the three doses $(5 \mu \mathrm{g} / \mathrm{mL}$, 

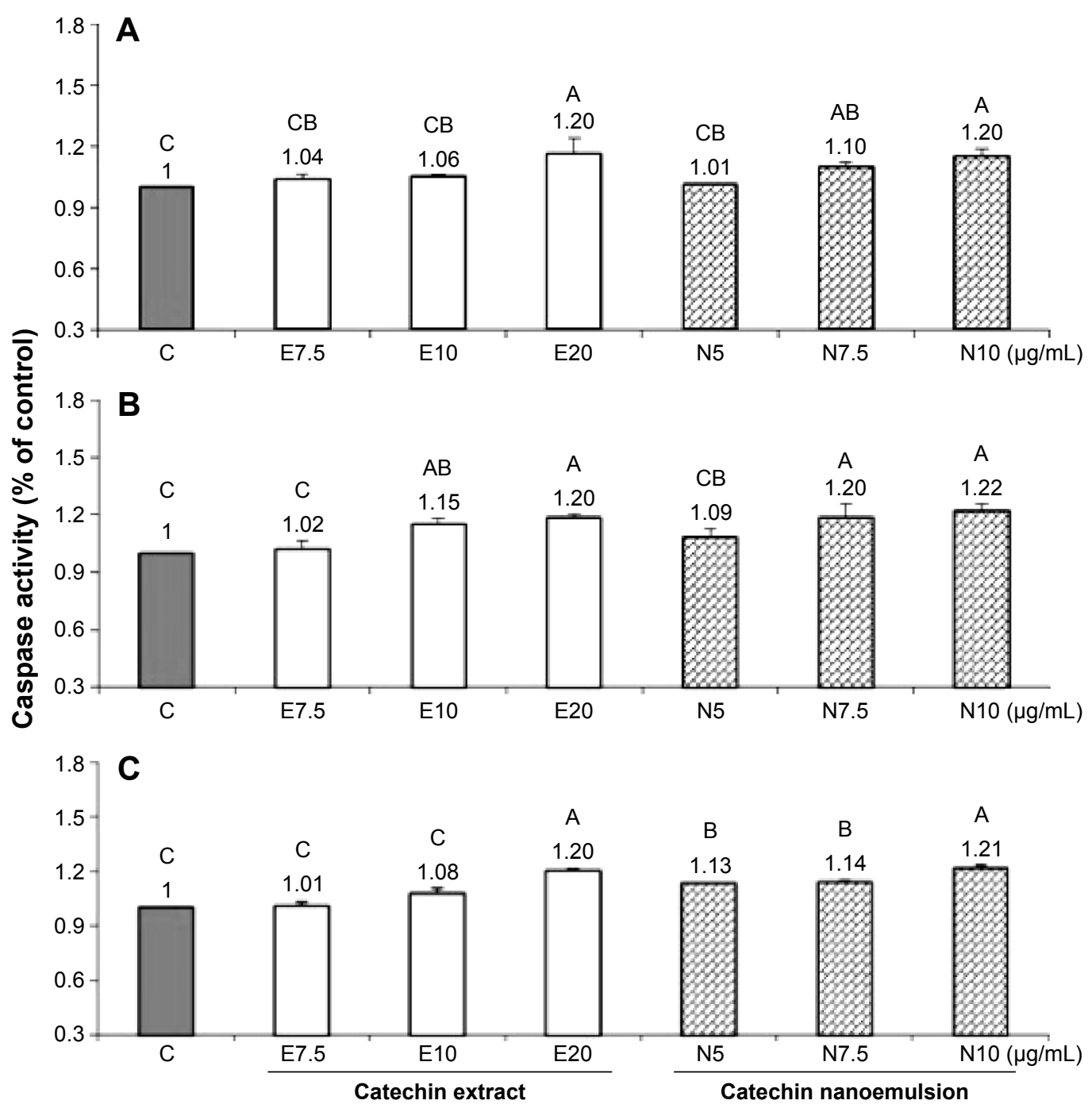

Figure 6 Activities of caspase-3 (A), caspase-8 (B), and caspase-9 (C) in PC-3 prostate cancer cells as affected by catechin extract and nanoemulsion from green tea leaf waste.

Notes: Results are presented as mean \pm standard deviation of triplicate analyses. Data with different capital letters (A-C) on each bar represent the caspase activity in PC-3 cells at different concentrations of catechin extract or nanoemulsion and are significantly different at $P<0.05$ compared to control. The abbreviations used in $X$-axes indicate control $(\mathrm{C})$, catechin extract $(\mathrm{E})$, and catechin nanoemulsion $(\mathrm{N})$.

$7.5 \mu \mathrm{g} / \mathrm{mL}$, and $10 \mu \mathrm{g} / \mathrm{mL})$ of catechin nanoemulsion showed a significantly higher $(P<0.05)$ caspase-9 activity than control by 1.13-, 1.14-, and 1.21-fold, respectively.

In several other studies, Singh et al ${ }^{62}$ reported that after treatment of cervical cancer cells SiHa with EGCG $(10 \mu \mathrm{g} / \mathrm{mL})$ for 24 hours, both activities of caspase-3 and caspase-9 were enhanced while the bcl-2 expression decreased, leading to cytochrome $\mathrm{C}$ release and formation of cleaved poly(ADP-ribose) polymerase for subsequent apoptosis. Similarly, the cytochrome $\mathrm{C}$ was shown to release from mitochondria into cytoplasm to lower ATP level, accompanied by an increase in caspase- 3 activity, resulting in apoptosis of prostate cancer cell PC-3 after treatment with black tea extract $(0.4 \mathrm{mg} / \mathrm{mL}) .{ }^{63}$ In a recent study dealing with the effect of EGCG and EGCG-chitosan nanoparticles on prostate cancer cells LNCaP and PC-3, the bcl-2 expression followed a dose-dependent decline accompanied by formation of cleaved caspase-3, -7, -8, -9 and poly(ADP-ribose) polymerase in a dose-dependent manner, leading to apoptosis of both LNCaP and PC-3 cells. ${ }^{50}$

Collectively, all the results shown previously revealed that both catechin extract and nanoemulsion could lead to apoptosis of cancer cells probably through caspasedependent pathway. However, as the activities of caspase-3, caspase-8, and caspase-9 were only slightly higher than the control treatment, some other caspase-independent pathways may also be involved for apoptosis of PC-3 cells. In a study dealing with the effect of EGCG $(25-200 \mu \mathrm{M})$ on 
apoptosis of human laryngeal epidermoid cancer cells Hep2, the p53 expression was elevated and both expressions of bcl-2 and bid declined, while the expressions of caspase-3, $-8,-9$ remained unaffected, accompanied by a drop in the mitochondria membrane potential, leading to release of cytochrome C, apoptosis-inducing factor (AIF), and nucleic acid Endo G into cytoplasm for apoptosis to occur. ${ }^{64}$ The same phenomenon was shown after treatment of leukemia cells K562 with EGCG $(200 \mu \mathrm{M})$; both cytochrome C and AIF were released from mitochondria into cytoplasm, while the caspase- 3 activity remained unaffected. ${ }^{65}$ Thus, the apoptosis of leukemia cells K562 was postulated to occur through caspase-independent pathway. As AIF was present in interspace of mitochondria membrane, the mitochondria permeability could be changed when cells were externally stimulated. This could result in a transfer of AIF into nucleus for chromatin condensation and DNA fragmentation, leading to apoptosis. Taken together, our study demonstrated that both catechin extract and nanoemulsion could induce apoptosis of prostate cancer cell PC-3 probably through caspase-dependent or caspase-independent pathway.

\section{Conclusion}

An HPLC-MS method was developed to separate and quantify various catechins in green tea leaf waste, in which EGCG was present in the largest amount, followed by ECG, GCG, EGC, and GC. The catechin nanoemulsion composed of catechin extract, $0.5 \%$ lecithin, $5 \%$ Tween 80 , and $94.5 \%$ deionized water was successfully prepared with the mean particle size being $11.45 \mathrm{~nm}$, polydispersity 0.27 , encapsulation efficiency $88.1 \%$, and zeta potential $-66.3 \mathrm{mV}$. A high stability of the catechin nanoemulsion was shown over a storage period of 120 days at $4^{\circ} \mathrm{C}$. Both catechin extract and nanoemulsion could inhibit prostate cancer cell $\mathrm{PC}-3$ proliferation, with the $\mathrm{IC}_{50}$ being $15.4 \mu \mathrm{g} / \mathrm{mL}$ and $8.5 \mu \mathrm{g} / \mathrm{mL}$, respectively. In addition, the cell cycle of PC-3 was arrested at S phase through increase of $\mathrm{P} 27$ expression and decrease of cyclin A, cyclin B, CDK2, and CDK1 expressions. In addition, both catechin extract and nanoemulsion could induce apoptosis of PC-3 cells through decline of bcl- 2 expression and elevation of cytochrome $\mathrm{C}$ expression for activation of caspase-3, caspase-8, and caspase-9. Nevertheless, the PC-3 cell apoptosis may also occur through caspase-independent pathway.

\section{Acknowledgment}

The authors wish to thank Mr Yen-Sheng Wu from Tzong Jao Hang's Electron Microscope Laboratory, School of Medicine, Fu Jen Catholic University, Taipei, Taiwan for technical assistance in recording the transmission electron microscopic image.

\section{Disclosure}

The authors report no conflicts of interest in this work.

\section{References}

1. Hu JY, Tsai YR, Lin SF. Present Status and Potential of Application of DNA Molecule Marker in Tea Tree. Taipei: Biotech Industry Research Center, Taiwan Economic Research Institute; 2011.

2. Annual Report of Ministry of Economics, Product Statistics, Taipei City, Taiwan; 2015.

3. Tsai CF, Hsu YW, Ting HC, Huang CF, Yen CC. The in vivo antioxidant and antifibrotic properties of green tea (Camellia sinensis, Theaceae). Food Chem. 2013;136(3-4):1337-1344.

4. Cavet ME, Harrington KL, Vollmer TR, Ward KW, Zhang JZ. Antiinflammatory and anti-oxidative effects of the green tea polyphenol epigallocatechin gallate in human corneal epithelial cells. Mol Vis. 2011; 17:533-542.

5. Carvalho M, Jeronimo C, Valentao P, Andrade PB, Silva BM. Green tea: a promising anticancer agent for renal cell carcinoma. Food Chem. 2010;122(1):49-54.

6. Kim YJ, Houng SJ, Kim JH, Kim TR, Ji HG, Lee SJ. Nanoemulsified green tea extract shows improved hypocholesterolemic effects in C57BL/6 mice. J Nutr Biochem. 2012;23(2):186-191.

7. Senanayake SPJN. Green tea extract: chemistry, antioxidant properties and food applications - a review. J Funct Foods. 2013;5(4):1529-1541.

8. Choung MG, Hwang Y, Lee MS, Lee J, Kang ST, Jun TH. Comparison of extraction and isolation efficiency of catechins and caffeine from green tea leaves using different solvent systems. Int J Food Sci Technol. 2014;49(6):1572-1578.

9. Yeh DP. Comparison of antioxidant and anti-bacteria activity of tea leave wastes by different extraction method. Chia-Nan Pharmacology and Science University, Tainan City, Taiwan; 2004.

10. Vuong QV, Golding JB, Nguyen M, Roach PD. Extraction and isolation of catechins from tea. J Sep Sci. 2010;33(21):3415-3428.

11. Liang H, Liang Y, Dong J, Lu J. Tea extraction methods in relation to control of epimerization of tea catechins. J Sci Food Agric. 2007;87(9): $1748-1752$.

12. Chen Y, Jiang Y, Duan J, Shi J, Xue S, Kakuda Y. Variation in catechin contents in relation to quality of 'Huang Zhi Xiang' Oolong tea (Camellia sinensis) at various growing altitudes and seasons. Food Chem. 2010;119(2):648-652.

13. Sharma A, Zhou W. A stability study of green tea catechins during the biscuit making process. Food Chem. 2011;126(2):568-573.

14. Ministry of Health. Statistics of Cause of Death. Taipei: Ministry of Health Publications; 2014.

15. Dube A, Nicolazzo JA, Larson I. Chitosan nanoparticles enhance the intestinal absorption of the green tea catechins (+)-catechin and (-)-epigallocatechin gallate. Eur J Pharm Sci. 2010;41(2):219-225.

16. Kale A, Gawande S, Kotwal S, et al. Studies on the effects of oral administration of nutrient mixture, quercetin and red onions on the bioavailability of epigallocatechin gallate from green tea extract. Phytother Res. 2010;24(suppl 1):48-55.

17. Lante A, Friso D. Oxidative stability and rheological properties of nanoemulsion with ultrasonic extracted green tea infusion. Food Res Int. 2013;54(1):269-276.

18. Prasad S, Kaur J, Roy P, Kalra N, Shukla Y. Theaflavins induce G2/M arrest by modulating expression of $\mathrm{p} 21^{\text {wafl/cip } 1}, \operatorname{cdc} 25 \mathrm{C}$ and cyclin $\mathrm{B}$ in human prostate carcinoma PC-3 cells. Life Sci. 2007;81(17-18): 1323-1331.

19. Lin SD, Mau JL, Hsu CA. Bioactive components and antioxidant properties of $\gamma$-aminobutyric acid (GABA) tea leaves. LWT Food Sci Technol. 2012;46(1):64-70. 
20. Vuong QV, Golding JB, Stathopoulos CE, Nguyen MH, Roach PD. Optimizing conditions for the extraction of catechins from green tea using hot water. J Sep Sci. 2011;34(21):3099-3106.

21. Lin LZ, Chen P, Harnly JM. New phenolic components and chromatographic profiles of green and fermented teas. J Agric Food Chem. 2008; 56(17):8130-8140.

22. Wu C, Xu H, Heritier J, Andlauer W. Determination of catechins and flavonol glycosides in Chinese tea varieties. Food Chem. 2012;132(1): 144-149.

23. International Conference on Harmonization (ICH). Guideline on the validation of analytical procedures, Methodology Q2B. International Conference on Harmonization (ICH), Geneva, Switzerland; 2013.

24. Chang HB, Chen BH. Inhibition of lung cancer cells A549 and H460 by curcuminoid extracts and nanoemulsions prepared from Curcuma longa Linnaeus. Int J Nanomed. 2015;10:5059-5080.

25. Statistical Analysis System (SAS). SAS Procedures and SAS/Graph User's Guide, Version 6. Cary, NC: SAS Institute, Inc.; 2014.

26. Xia T, Shi S, Wan X. Impact of ultrasonic-assisted extraction on the chemical and sensory quality of tea influsion. J Food Eng. 2006;74(4): $557-560$.

27. Friedman M, Levin CE, Choi SH, Kozukue E, Kozukue N. HPLC analysis of catechins, theaflavins, and alkaloids in commercial teas and green tea dietary supplements: comparison of water and $80 \%$ ethanol/ water extracts. J Food Sci. 2006;71(6):328-337.

28. Spacil Z, Novakova L, Solich P. Comparison of positive and negative ion detection of tea catechins using tandem mass spectrometry and ultra high performance liquid chromatography. Food Chem. 2010;123(2): 534-541.

29. Rahim AA, Nofrizal S, Saad B. Rapid tea catechins and caffeine determination by HPLC using microwave-assisted extraction and silica monolithic column. Food Chem. 2014;147:262-268.

30. Pelillo M, Bonoli M, Biguzzi B, Bendini A, Toschi TG, Lercker G. An investigation in the use of HPLC with UV and MS-electrospray detection for the quantification of tea catechins. Food Chem. 2004;87(3):465-470.

31. Bonoli M, Pelillo M, Toschi TG, Lercker G. Analysis of green tea catechins: comparative study between HPLC and HPCE. Food Chem. 2003;81(4):631-638.

32. Wang H, Provan GJ, Helliwell K. HPLC determination of catechins in tea leaves and tea extracts using relative response factors. Food Chem. 2003;81(2):307-312.

33. Wang D, Lu J, Miao A, Xie Z, Yang D. HPLC-DAD-ESI-MS/MS analysis of polyphenols and purine alkaloids in leaves of 22 tea cultivars in China. J Food Compost Anal. 2008;21(5):361-369.

34. Wang Y, Yang X, Li K, et al. Simultaneous determination of theanine, gallic acid, purine alkaloids, catechins, and theaflavins in black tea using HPLC. Int J Food Sci Technol. 2010;45(6):1263-1269.

35. Peng L, Song X, Shi X, Li J, Ye C. An improved HPLC method for simultaneous determination of phenolic compounds, purine alkaloids and theanine in Camellia species. J Food Compost Anal. 2008;21(7): 559-563.

36. Zou LQ, Peng SF, Liu W, et al. Improved in vitro digestion stability of (-)-epigallocatechin gallate through nanoliposome encapsulation. Food Res Int. 2014;64:492-499.

37. Gadkari PV, Balarman M. Extraction of catechins from decaffeinated green tea for development of nanoemulsion using palm oil and sunflower oil based lipid carrier systems. J Food Eng. 2015;147:14-23.

38. Srivastava AK, Bhatnagar P, Singh M, et al. Synthesis of PLGA nanoparticles of tea polyphenols and their strong in vivo protective effect against chemically induced DNA damage. Int J Nanomed. 2013; 8:1451-1462.

39. Silva HD, Cerqueira MA, Vicente AA. Nanoemulsions for food applications: development and characterization. Food Bioprocess Technol. 2011;5(3):854-867.

40. Huang YB, Tsai MJ, Wu PC, Tsai YH, Wu YH, Fang FY. Elastic liposomes as carriers for oral delivery the brain distribution of $(+)$-catechin. J Drug Target. 2011;19(8):709-718.
41. Pace RCD, Liu X, Sun M, et al. Anticancer activities of (-)-epigallocatechi3-gallate encapsulated nanoliposomes in MCF7 breast cancer cells. J Liposome Res. 2013;23(3):187-196.

42. Hu B, Ting Y, Zeng X, Huang Q. Bioactive peptides/chitosan nanoparticles enhance cellular antioxidant activity of (-)-epigallocatechin3-gallate. J Agric Food Chem. 2013;61(4):875-881.

43. Ponnuraj R, Janakiraman K, Gopalakrishnan S, Senthilnathan K, Meganathan V, Saravanan P. Formulation and characterization of epigallocatechin gallate nanoparticle. Indo Am J Pharm Res. 2015; 5:387-399.

44. Lippert C, Seeger H, Mueck AO. The effect of endogenous estradiol metabolites on the proliferation of human breast cancer cells. Life Sci. $2003 ; 72(8): 877-883$.

45. Lin C. Effect of brewed beer yeast extract on inhibition of lung cancer cells. MS Thesis, Fu Jen Catholic University, 2013.

46. Li Y, Maux S, Xiao H, McClements DJ. Emulsion-based delivery systems for tributyrin, potential colon cancer preventative agent. J Agric Food Chem. 2009;57(19):9243-9249.

47. Schöler N, Olbrich C, Tabatt K, Muller RH, Hahn H, Liesenfeld O. Surfactant, but not the size of solid lipid nanoparticles (SLN) influences viability and cytokine production of macrophages. Int J Pharm. 2001; 221(1-2):57-67.

48. Adhami VM, Malik A, Zaman N, et al. Combined inhibitory effects of green tea polyphenols and selective cyclooxygenase- 2 inhibitors on the growth of human prostate cancer cells both in vitro and in vivo. Clin Cancer Res. 2007;13(5):1611-1619.

49. Albrecht CS, Clubbs EA, Ferruzzi M, Bomser JA. Epigallocatechin3-gallate (EGCG) inhibits PC-3 prostate cancer cell proliferation via MEK-independent ERK1/2 activation. Chem Biol Interact. 2008;171(1):89-95.

50. Shabana SM, Siddiqui IA, Khan N, et al. Antiproliferative and proapoptotic effects of (-)-epigallocatechin-3-gallate encapsulated in chitosan nanoparticles on human prostate carcinoma cells. $J$ Pharm Pharmacol. 2014;2:1-7.

51. Ravindranath MH, Saravanan TS, Monteclaro CC, et al. Epicatechins purified from green tea (Camellia sinensis) differentially suppress growth of gender-dependent human cancer cell lines. Evid Based Complement Alternat Med. 2006;3(2):237-247.

52. Thangapazham RL, Singh AK, Sharma A, Warren J, Gaddipati JP, Maheswari RK. Green tea polyphenols and its constituent epigallocatechin gallate proliferation of human breast cancer cells in vitro and in vivo. Cancer Lett. 2007;245(1-2):232-241.

53. Siddiqui IA, Bharali DJ, Nihal M, et al. Excellent anti-proliferative and pro-apoptotic effects of (-)-epigallocatechin-3-gallate encapsulated in chitosan nanoparticles on human melanoma cells growth both in vitro and in vivo. Nanomed Nanotech Biol Med. 2014;10(8): 1619-1626.

54. Zhao H, Zhang M, Zhao L, Ge YK, Sheng J, Shi W. Changes of constituents and activity to apoptosis and cell cycle during fermentation of tea. Int J Mol Sci. 2011;12(3):1862-1875.

55. Thakur VS, Gupta K, Gupta S. Green tea polyphenols causes cell cycle arrest and apoptosis in prostate cancer cells by suppressing class I histone deacetylases. Carcinogenesis. 2011;33(2):377-384.

56. On-Ki L, Mei Y, Hong-Yeung C. Growth inhibition and cell cycle arrest effects of oolong tea polyphenol extract on human hepatoma and prostate cancer cells. Hong Kong Pharm J. 2011;18(1): 24-30.

57. Chen CC, Hsieh D, Huang KJ, et al. Improving anticancer efficacy of (-)-epigallocatechin-3-gallate gold nanoparticles in murin B16F10 melanoma cells. Drug Des Dev Ther. 2014;8:459-474.

58. Gupta S, Hussain T, Mukhtar H. Molecular pathway for (-)-epigallocatechin-3-gallate-induced cell cycle arrest and apoptosis of human prostate carcinoma cells. Arch Biochem Biophys. 2003;410(1):177-185.

59. Peng L, Khan N, Afaq F, Ye C, Mukhtar H. In vitro and in vivo effects of water extract of white cocoa tea (Camellia ptilophylla) against human prostate cancer. Pharm Res. 2010;27(6):1128-1137. 
60. Lim YC, Cha YY. Epigallocatechin-3-gallate induces growth inhibition and apoptosis of human anaplastic thyroid carcinoma cells through suppression of EGFR/ERK pathway and cyclin B1/CDK1 complex. J Surg Oncol. 2011;104(7):7760-7780.

61. Singh T, Katiyar SK. Green tea polyphenol, (-)-epigallocatechin3 -gallate, induces toxicity in human skin cancer cells by targeting $\beta$-catenin signaling. Toxicol Appl Pharmacol. 2013;273(2):418-424.

62. Singh M, Bhui K, Singh R, Shukla Y. Tea polyphenols enhance cisplatin chemosensitivity in cervical cancer cells via induction of apoptosis. Life Sci. 2013;93(1):7-16.
63. Sun S, Pan S, Miao A, et al. Active extracts of black tea (Camellia sinensis) induce apoptosis of $\mathrm{PC}-3$ prostate cancer cells via mitochondrial dysfunction. Oncol Rep. 2013;30(2):763-772.

64. Lee JH, Jeong Y, Lee SW, et al. EGCG induces apoptosis in human laryngeal epidermoid carcinoma Hep2 cells via mitochondria with the release of apoptosis-inducing factor and endonuclease G. Cancer Lett. 2010;290(1):68-75.

65. Iwasaki R, Ito K, Ishida $\mathrm{T}$, et al. Catechin, green tea component, causes caspase-independent necrosis-like cell death in chronic myelogenous leukemia. Cancer Sci. 2009;100(2):349-356.

\section{Publish your work in this journal}

The International Journal of Nanomedicine is an international, peerreviewed journal focusing on the application of nanotechnology in diagnostics, therapeutics, and drug delivery systems throughout the biomedical field. This journal is indexed on PubMed Central, MedLine, CAS, SciSearch ${ }^{\circledR}$, Current Contents ${ }^{\circledR} /$ Clinical Medicine,
Journal Citation Reports/Science Edition, EMBase, Scopus and the Elsevier Bibliographic databases. The manuscript management system is completely online and includes a very quick and fair peer-review system, which is all easy to use. Visit http://www.dovepress.com/ testimonials.php to read real quotes from published authors. 